\title{
EDWARD CHANEY
}

\author{
R.B. Kitaj (1932-2007): Warburgian Artist
}

\begin{abstract}
This essay examines the influence of Aby Warburg and the Warburg Institute, as mediated by Edgar Wind, on R.B. Kitaj from the late 1950s until his death in 2007. It is based on research in the National Portrait Gallery, the Warburg Institute Archive, the Wind archives in Oxford, Kitaj's unpublished autobiography and correspondence between the author and the artist dating back to 1972. It explores Kitaj's creative response to Warburg's brand of cultural history which encouraged his early eschewal of the prevailing focus upon formal values in favour of 'symbolic images' and suggestive content. This tendency was enhanced by his increasing celebration of his Jewishness and aspirations towards the creation of 'a Jewish art like the Egyptian figurative style'. Kitaj's portrait of Ernst Gombrich (1986) was commissioned by the National Portrait Gallery at a time when he was becoming obsessed with his Jewish project while Gombrich was confirming his rejection of the category Jewish, in other than a religious context, altogether. Discussion of Jewishness and the arts in the twentieth century is supplemented by the identification of David Allan's Origin of Painting (done in Italy in 1775) as the inspiration for Kitaj's Los Angeles series of pictures in which his late, lamented wife is depicted as the Hebrew deity, Shekinah.
\end{abstract}

'Symbolic forms are coined in the depths of human experiences...' from Fritz Saxl's lecture on 'Warburg's Visit to New Mexico'1

'... invent a Jewish style, like the Egyptian figure style... ABY WARBURG: Jewish Prophet of my Oxford youth (see my Confessions of an Old Jewish Painter, soon to be published). He was (aside from Berenson perhaps) the father of modern art history, and one of the great influences on my painting and aesthetic life.' R.B. Kitaj, Second Diasporist Manifesto. ${ }^{2}$

\footnotetext{
*This is an extended and revised version of an essay originally commissioned by the Jewish Museum in Berlin for their exhibition catalogue, Kugelmann, Gillen and Gaßner, 2012, pp. 97-103. I thank the Museum and its staff, as well as Eckhart Gillen, co-curator of the exhibition and catalogue, for their help and for supplying me with a copy of Kitaj's unpublished Confessions (herein cited Kitaj, n.d.). For permission to quote from the Confessions and for other encouragements, I thank Kitaj's eldest son, Lem Dobbs, and the Kitaj estate. I would also like to thank Elizabeth McGrath for suggesting I write this article in the first place and Giles Fielke for seeing it through to publication in this form.

${ }^{1}$ Quoted by Kitaj, 1963, p. 8.

${ }^{2}$ Kitaj, 2007, nos 70 and 118.
} 


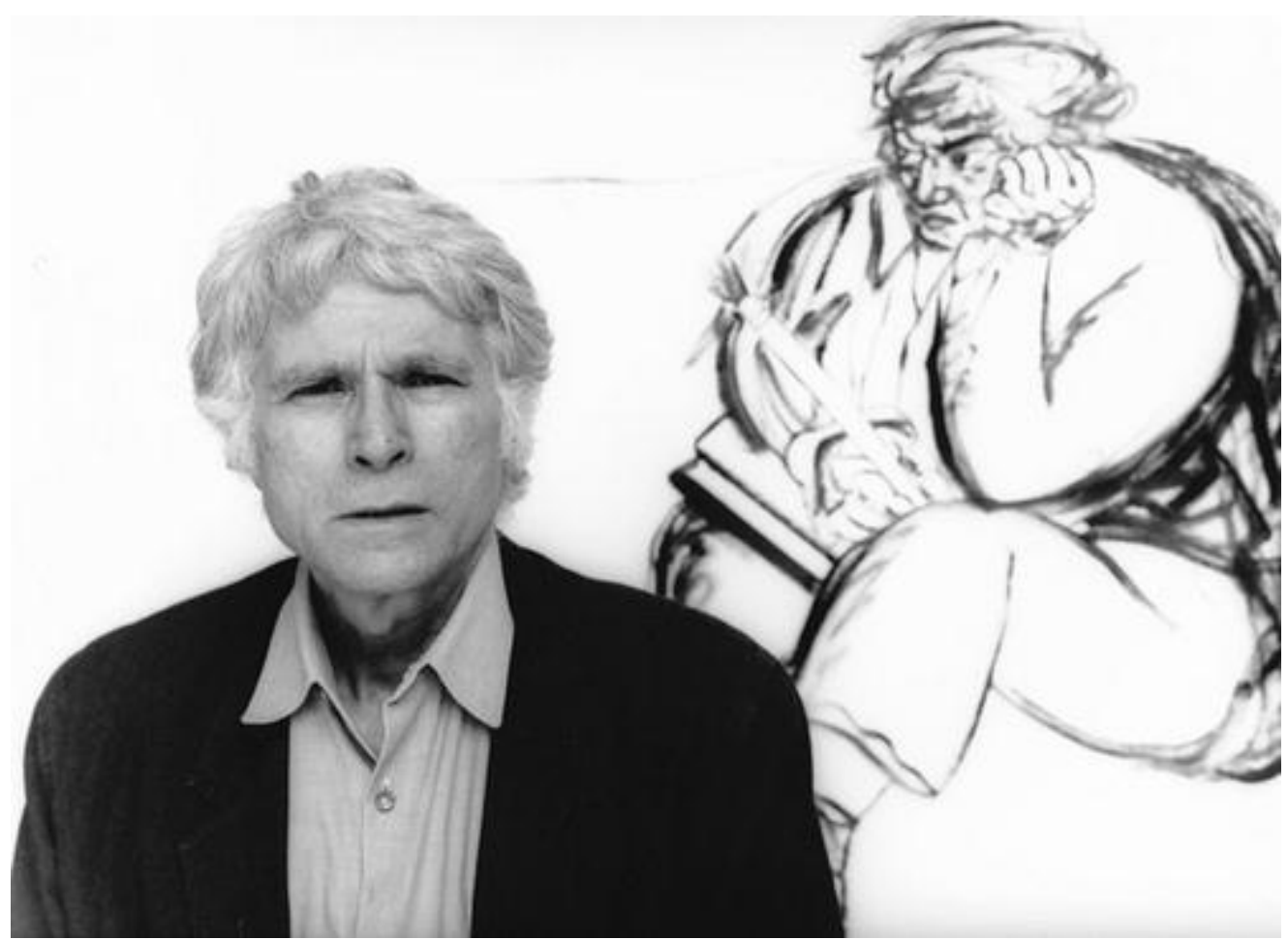

Fig. 1. Photograph of R.B. Kitaj at Elm Park Road soon after his heart attack, with unfinished Melancholy after Dürer (1989). (Copyright Jonathan Player.)

In the summer of 1986, after almost a year in which it had proved impossible to arrange a sitting with Lucian Freud, the National Portrait Gallery instead commissioned the American-born R.B. Kitaj to portray Professor Sir Ernst Gombrich, director of the Warburg Institute from $1959-76$ (Fig. 2). ${ }^{3}$ Kitaj's particular appropriateness for this task could hardly have been as clear to the commissioners, or indeed to Gombrich (whose wife, Ilse, asked to see reproductions of his work before they committed to the sitting), as it must have been to the artist himself. ${ }^{4}$ For Kitaj's entire aesthetic, based as it was in the symbolic forms of an intensely personal iconology, was profoundly indebted to Aby Warburg and the legacy associated with

\footnotetext{
${ }^{3}$ See the correspondence in the National Portrait Gallery, London (NPG, NPG46/59/79, Registered Packet 5892). I reproduced this portrait in Chaney, 2002, p.111. There are two articles by Gombrich in the Kitaj archives at UCLA, R.B. Kitaj Papers, Box 102, Folder 25 (1981).

${ }^{4}$ A typed memo dated 18 June 1986 in the NPG file records a phone message from Gombrich for John Hayes, the director, stating that: 'His wife feels that she wishes to see one of Kitaj's portraits before they go ahead.' This was arranged through Geoffrey Parton at the Marlborough Gallery. Interestingly, a more cryptic, handwritten memo records: 'O.k. - wd. have liked Gowing' (i.e. the artist and art historian Lawrence Gowing whom Kitaj was to describe as 'the best art-writer in the world'; Kitaj, n.d., p. 194). Kitaj included Gowing in his Human Clay exhibition at the Hayward Gallery in 1976. Though Kitaj's 1985 portrait of Lord Sieff is referred to it is also interesting that his Jewish Rider, dating from the previous year, was not mentioned in the relevant correspondence given that it was a portrait of Michael Podro (1931-2008), whose PhD dissertation Gombrich had co-supervised and who indeed taught at the Warburg Institute from 1967 but was not selected for a full-time position a few years later (when David Chambers was appointed). Podro's father was the Judaic scholar Joshua Podroznic, who published The Nazarene Gospel Restored in 1953. For the picture (and photograph) of Podro, see Kugelmann, Gillen, Gassner, 2012, p. 139.
} 
the institution he created in Hamburg, which in 1933 had relocated to London. Interviewed in 2000 Gombrich took partial responsibility for what he eventually regarded as the failure of his portrait:

On the second day of our sittings the first sketch showed a happy grin. I should not have intervened, but I asked him to wipe it off my face, and as a result, to my mind the features have no coherent expression at all. ${ }^{5}$

It could in fact be argued that the somewhat wary half-smile that survives in the completed portrait makes it all the more effective as a work of art and that, as in times past, the interaction between patron and artist (in this case sitter and artist, for it was the state that paid the $£ 19,500$ fee), proved beneficial. Though politely describing it to the director of the NPG as 'splendid' in October 1986, however, Gombrich clearly ended up disliking the portrait, not coincidentally, one suspects, because his wife, Ilse, liked it even less (had the NPG not owned this superb picture it might conceivably have suffered the fate of Graham Sutherland's portrait of Churchill). Gombrich later recalled that he: 'went so far as to offer the Director of the NPG to stand next to the portrait, and give a lecture on the problems of portrait likeness - an offer which, luckily, was refused. ${ }^{6}$

Gombrich's critical response to what he, at least retrospectively, regarded as an unflattering image may also have related to his discovery of both the extent and nature of Kitaj's enthusiasm for Warburg and that Kitaj's introduction to Warburgianism had been at the hands of the latter's devoted disciple, Edgar Wind (1900-1971) (Fig. 3). Although both men seem to have enjoyed the ' 8 or 10 ' two-hour sittings, it is clear from Kitaj's recollection that their conversation included 'modern Jewish history'; that Gombrich would also have discovered the extent to which it had been due to the influence of Warburg, Wind and Fritz Saxl, as well as Sigmund Freud and Walter Benjamin, that Kitaj had come to embrace his own Jewishness and what he

\footnotetext{
${ }^{5}$ NPG, NPG46/59/79, Registered Packet 5892, typescript note.

${ }^{6}$ Ibid. By 1994, in the speech Gombrich made when presented with his $85^{\text {th }}$ birthday Festschrift, Charles Saumarez Smith recalls he was 'contemptuous of his portrait by R.B. Kitaj' (Saumarez Smith, 2006, http://www.theguardian.com/books/2006/dec/02/art; accessed 28 November 2013). 1994 was the year of Kitaj's fateful Tate Gallery retrospective.
} 
increasingly identified as a distinctively, indeed defiantly, Jewish, and 'diasporist' cultural legacy. ${ }^{7}$

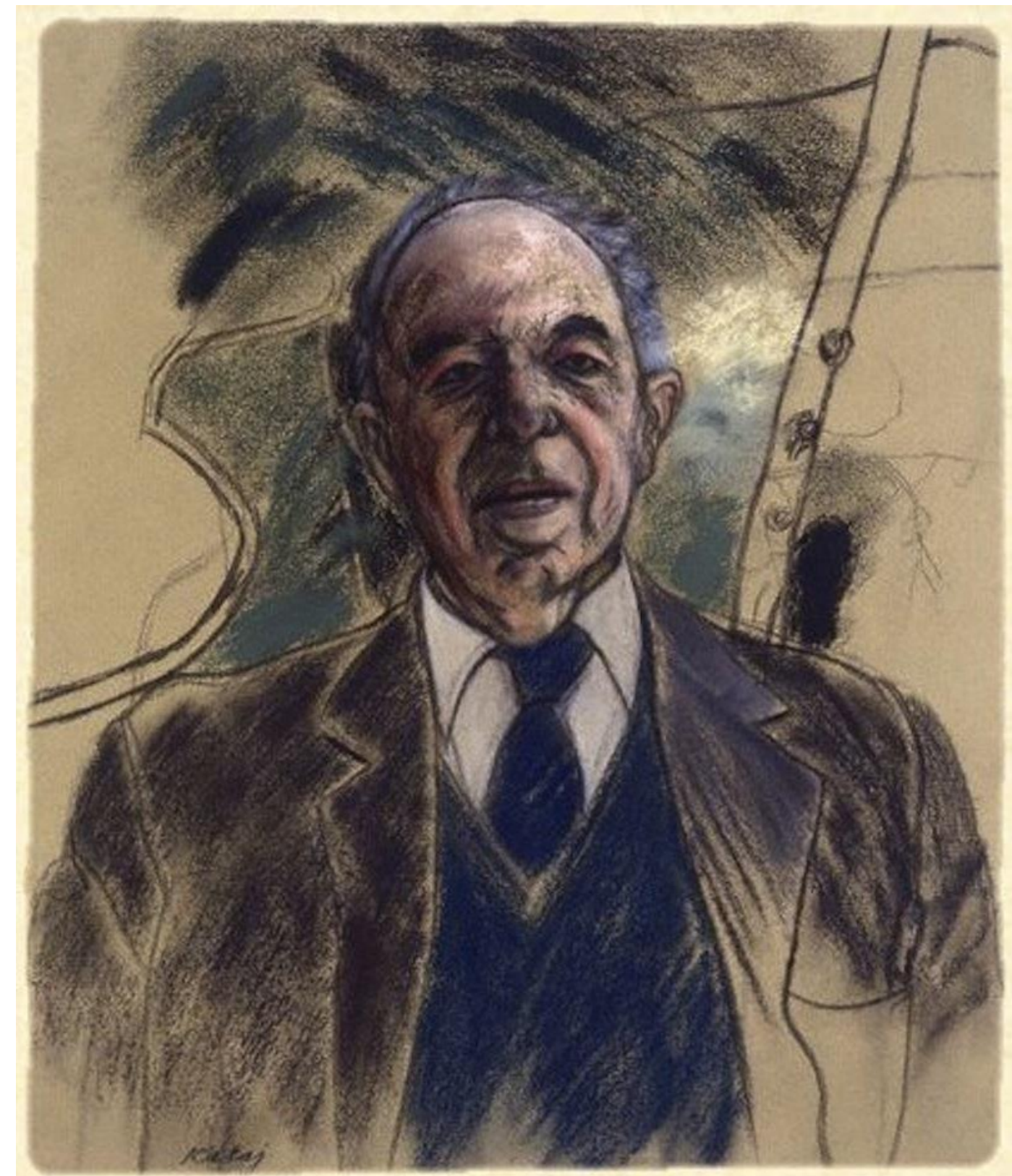

Fig. 2. R.B. Kitaj, Sir Ernst Hans Josef Gombrich, 1986. Pastel and charcoal, 67.6 x $57.8 \mathrm{~cm}$ London, National Portrait Gallery, inv. no. NPG 5892 (National Portrait Gallery).

\footnotetext{
${ }^{7}$ In the NPG file is a letter dating from November 1992 to Robin Gibson in which Kitaj refers to the '8 or 10 sessions... each session about 2 hrs long at my studio in Elm Park Rd.' He writes that he 'enjoyed great conversations with both men [Gombrich and Lord Sieff] while I worked... Gombrich, of course, is a goldmine of insight into art. Both sitters seem to enjoy talking about aspects of modern Jewish history as well - which I had been immersing myself in at that period. We became very affectionate with each other in both cases. I think the portraits came out well and I'm grateful to the NPG for pushing me out of my hermit's cave to the do the job. I do however envy Picasso and others who don't worry too much about getting a likeness.' He then goes on to emphasize that he does not want the proposed loans of the portraits to jeopardize their availability 'for my TATE - LACMA MET retrospective which begins at the Tate in Spring 94!!'
} 
Gombrich's distancing of himself, meanwhile, from what Kitaj regarded as their common heritage was of a piece with the lack of status he accorded Robert Vischer's 'Einfuhlung' or 'empathy' (in both aesthetic and more commonplace senses), a feature critiqued by Wind in his Times Literary Supplement review of Gombrich's 1970 Intellectual Biography of Warburg. ${ }^{8}$ If Gombrich ultimately failed to empathize with Warburg it may have been due both to his discomfort with the latter's emphasis on the irrational or 'Dionysian depths' and his views on the relationship between these and his history of mental illness, what Wind euphemistically calls in his review: 'the more volatile side of Warburg's personality. ${ }^{99}$ While Gombrich cautiously articulated reservations about Warburg's methods rather than his madness, Kitaj was happier to dwell on the latter and in still clearer contrast with Gombrich, the significance of their mutual Jewishness. ${ }^{10}$

Where the concept of Jewishness in anything other than a religious context was concerned, Gombrich was to articulate his views in a lecture he delivered in November 1996 after being invited by the Austrian Cultural Institute in London to speak about Jewish influences on the visual arts at a seminar on 'Fin de Siècle Vienna and its Jewish Cultural Influences.' He responded to this request, according to his host Emil Brix, with 'restrained fury', but eventually agreed to participate with an essaycum-manifesto which included the sentence: 'Of course I know many very cultured Jews, but, briefly, I am of the opinion that the notion of Jewish Culture was, and is, an

\footnotetext{
8 'Unfinished Business: Aby Warburg and his Work', Times Literary Supplement, 25 June 1971, p. 735, published anonymously but reprinted in Wind, 1983, pp. 106-13. See Charles Hope's review of the latter and subsequent correspondence: 'Naming the Graces', a review of Kenneth Clark's Art of Humanism and Wind's Eloquence of Symbols (Hope, 1984). Subsequent correspondence includes Gombrich's reference to 'the book [Wind] found it his duty to drag through the mud' (Gombrich, 1984a, http://www.lrb.co.uk/v06/n06/letters; accessed 28 November 2013).

${ }^{9} T L S$ review as reprinted in Wind, 1983, p. 113. Though he married within Viennese Jewry (in 1936), Gombrich was less inclined to identify himself in terms of his Jewishness than pre-Holocaust figures such as Warburg and Freud: 'I have not the slightest wish to deny or to conceal my Jewish origins, but when I think of history, I think of Western culture rather than the culture of the ghetto, of which I know, perhaps, too little.' Gombrich, 1993, p. 28.

${ }^{10}$ Kitaj would no doubt have been as interested as Gombrich would have deplored the speculations of the psychiatrist credited with curing Warburg in the 1920s, Emil Kraepelin, co-discoverer of Alzheimer's disease. In the 1909 edition of his Textbook of Psychiatry he wrote that: 'the well-known example of the Jews, with their strong disposition towards nervous and mental disorders, teaches us that their extraordinarily advanced domestication may eventually imprint clear marks on the race.' Kraepelin cited in Brüne, 2007, pp. 2-21. Accessible from http://www.peh-med.com/content/2/1/21.
} 
invention of Hitler and his fore-runners and after-runners. ${ }^{11}$ Gombrich's stance on this issue clearly fails to do justice to the extraordinary contribution of pre-Nazi German and Austrian Jews to science and the humanities and art history in particular. $^{12}$

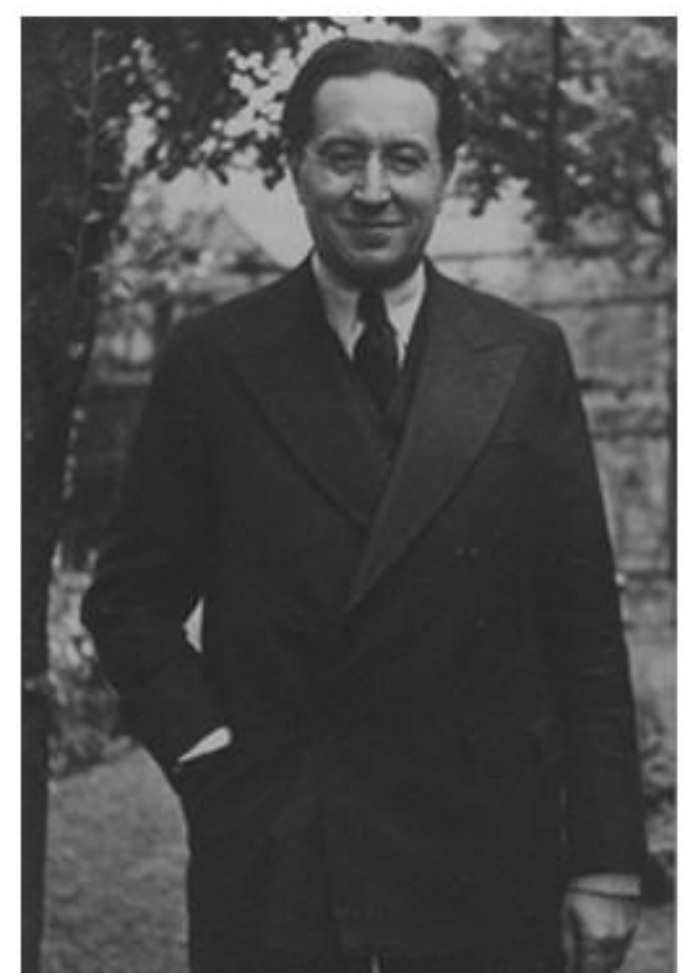

Fig. 3. Unknown photographer, Edgar Wind (copyright Wind Benefaction Committee for the Sackler Library, University of Oxford).

It is clear from what he says elsewhere that if Kitaj read this essay he would not have ceased celebrating what he regarded ever-more enthusiastically as the great Jewish contribution to Western civilization, least of all because Adolf Hitler had chosen to exploit racial distinction to such evil ends. His attitude to the subject accords more closely with what recent scholarship attributes to Warburg himself, inasmuch as it has

\footnotetext{
${ }^{11}$ Gombrich, 1997, p. 4. In A Lifelong Interest, Gombrich states 'No, I have never been touched by Jewish education,' (Gombrich, 1993, p.15). In a subsequent publication by the Austrian Cultural Institute, the late Siegbert Prawer documents Freud's acknowledgment of the significance of his Jewishness: 'Types and Stereotypes: Sigmund Freud's Portrayal of Jews in Greater Austria' in Occasions, 12 (London, 2011). Paolo Fabbri's views on Gombrich in a slightly different context may be pertinent here. He writes of Gombrich's 'appeal to simplicity', being 'not a refusal of theory; it is a product of his acculturation within the Anglo-Saxon system.' Fabbri, 2011, http://www.paolofabbri.it/saggi/beyond_gombrich.html; accessed 20 January 2013.

${ }^{12}$ It has been estimated that almost 25 per cent of pre-War German art historians were Jewish. Cf. Michels, 1999, p. 167. For the most recent celebration of Jewishness, see Schama, 2013.
} 
been argued that his life work was a culturally positive response to anti-Semitism. ${ }^{13}$ Famously Warburg described himself as: 'Ebreo di sangue - Amburghese di cuore Fiorentino di anima., 14

In this identification with his Jewish origins, as in his temperament more generally (including his tendency to manic-depression), Kitaj indeed resembled Warburg. ${ }^{15}$ If Kitaj embraced a more self-consciously libertarian life-style, both shared a similarly high-risk philosophy of life and art that adventurously - perhaps inevitably empathized with a wide range of phenomena in the context of the potentially tragic, Apollonian and Dionysian, yet de-polarized dualism implicit in William Blake's Marriage of Heaven and Hell: 'Without contraries is no progression., 16

Recalling his student days at the Ruskin School in Oxford in his fascinating, still unpublished Confessions, Kitaj acknowledged his debt to the charismatic Professor of Fine Art, Edgar Wind, in the following terms:

Wind led me to his master, Warburg, who died semi-mad in 1929 and Warburg led me to his legacy and to his legatees - Panofsky, Saxl, Bing, Wittkower, Otto Pacht, the younger Gombrich and all the rest. ${ }^{17}$

\footnotetext{
${ }^{13}$ See Schoell-Glass, 2008. From Kitaj's statement quoted below, it is possible that he had read, or at least heard of Dr Schoell-Glass's book in its original German manifestation (published in Frankfurtam-Main, 1998). See also her essay in Jewish Identity and Modern Art History (Schoell-Glass, 1999).

${ }^{14}$ See Gertrud Bing, 1960, p. 113. This quote also appears in Pollock, 2013, forthcoming.

${ }^{15}$ Depression ran in Warburg's family; his sister Olga committed suicide in 1904 and his son, Max, suffered from depression throughout his life and, like his father, was periodically institutionalized; see Chernow, 1993, pp. 79; 511-2.

${ }^{16}$ This itself dates back to Plato's ideas of reality and polarity as discussed by Goethe (Warburg's more immediate model); I owe this to an unpublished lecture by Andrea Pinotti: 'Origin vs Genesis: Warburg and Benjamin in the Footsteps of Goethe's Morphology', delivered at the Warburg Institute on 14 June 2012. Benjamin was himself a great admirer of Warburg and sent him a copy of his Habilitationsschrift, which Saxl duly filed away in the library. Kitaj produced a lithographic portrait of Benjamin in 1966; see Ramkalawon, 2013, p. 50, no. 23; cf. Kinsman, 1994, p. 41.

${ }^{17}$ Typescript, Confessions, corrected in Kitaj's hand, now in the possession of the Kitaj estate, Kitaj, n.d., p. 36. It is interesting that Kitaj here specifies 'the younger Gombrich'. I am very grateful to Lem Dobbs for permission to quote from this fascinating document and to publish it in its entirety though I gather that Eckhart Gillen will now be doing so. Wind was a member of the Committee for the Fine Arts at Oxford and thus shared responsibility for the supervision and instruction of degree candidates and for the administration of the Ruskin School at which Kitaj was registered in late 1956; see LloydJones, 1983, p. xxvii. On his registration card still at the Ruskin is recorded 'H of A. 1957. Commended. Anatomy 1957. Pass.'
} 
He continues: 'If Freud's circle and work can be thought of, by friends and enemies alike, as Jewish Science, then the Warburg tradition and persuasion is also Jewish, in ways not yet explored.' This linking of Freud and Warburg is surprisingly rare, despite common sources in Lessing and perhaps even Charcot, where the concept of Pathosformeln was concerned. ${ }^{18}$ Freud's 1907 essay Der Wahn und die Träume in W. Jensens 'Gradiva' suggests this common interest - if not inter-influence - examining as it does the profound psychological effect on a (fictional) archaeologist of an antique relief in the Vatican depicting a dancer of the type that Warburg claimed influenced Botticelli, resembling as it does those Maenads that so fascinated him and his followers. The erotically-charged exchanges between Warburg and his witty (but ultimately suicidal) Dutch friend André Jolle in Florence in 1900 on the subject of Ghirlandaio's 'Ninfa fiorentina' and their dreams (and photographs) of contemporary Florentine girls clearly anticipate Freud's interests in the subject. ${ }^{19}$ Freud's essay and Jensen's novel that inspired it, in turn inspired both Salvador Dali and André Masson to use this relief as a motif. Freud and Warburg certainly knew each other's work, and the former kept up-to-date regarding the latter's state of mind in the early 1920s when Warburg was placed in the care of Freud's younger colleague, Ludwig Binswanger, in the Kreuzlinger sanatorium on Lake Constance. ${ }^{20}$

One way or another, from his art school days in Oxford until his death in Los Angeles half a century later, Kitaj referenced every major figure in Warburg's Nachleben. Where the Institute in particular was concerned the relationship got off to a somewhat

\footnotetext{
18 Bergstein, 2010, p. 96. In his Confessions, Kitaj reveals that he underwent analysis for about a year with the editor of the Penguin Freud, Adam Phillips, in his last years in England. Deeper theoretical connections between Freud and Warburg are also suggested by Iversen, 1991. Kitaj's interest in Freud's dialectic between Eros and Thanatos complements his interest in Warburg's Nietzschean Apollo/Dionysian dualism. Another Warburgian dualism is highlighted by Kitaj as No. 138 of his Second Diasporist Manifesto: 'WARBURG, just before he died, wrote "Placed from my very birth in the middle between Orient and Occident..." Thus he declares a Jewish Diasporist essence - a debt, or legacy, or view or reach to the Mideast.' Kitaj, 2007.

${ }^{19}$ Roeck 2009, pp. 214-24; cf. Gombrich, 1986, pp. 105-27. See also Agamben, 2011, pp. 63-5.

${ }^{20}$ Roeck, 2009, pp. 249-50; Michaud, 2004, pp. 174-5. Gombrich states that his mother, through her cousin's husband, the paediatrician Max Kassowitz, who gave Freud his first important job in the 1880s, 'knew Freud very well.' (Gombrich, 1993, p. 16; cf. Ernest Jones, Sigmund Freud: Life and Work, I (1956), passim: 'My mother remembered spending several weeks with Freud during the summer holidays, and she was just as much at home in his house in Vienna... I have to say that she didn't like him much, though she always added that he was brilliant at telling Jewish stories.' It seems to have been Emil Kraepelin who saved Warburg, not least by downgrading his diagnosis from schizophrenia to manic-depression; see Marazia and Stimilli, 2007. See also the role played by Hans Prinzhorn, as summarized in Prinzhorn, 2011, http://ajp.psychiatryonline.org/data/Journals/AJP/4236/appi.ajp.2011.11040571.pdf; accessed 28 November 2013.
} 
tense start early on in Gombrich's directorship. As a 30-year-old rising star in London's artistic firmament, in 1963 Kitaj complained in the catalogue to his first major exhibition, at Marlborough Fine Art in London, that: 'The Warburg Institute has refused permission to reprint Saxl's lecture on Warburg from which I have quoted in the notes to my paintings. ${ }^{21}$ In the extended caption to the work he completed in collaboration with Eduardo Paolozzi: Warburg's visit to New Mexico (1960-2), Kitaj quoted long excerpts from Saxl's lecture in any case and, by way of protest, prefaced the whole by quoting Gertrud Bing's Memoir of her late partner on 'the laziness of heart that hides behind red tape. ${ }^{, 22}$ Having cited Bing on Saxl not keeping to the rules and lacking 'the proper respect for conventions,' Kitaj concluded with the clarification that: 'The late Fritz Saxl was the first director of the Warburg Institute'. Telling also, perhaps of Wind's critical influence, was Kitaj's statement within the catalogue entry to the painting-collage itself: 'Warburg's work has never been translated into English for reasons best known to those who control these sacrosanct matters'. ${ }^{23}$

Kitaj knew Bing as a near neighbour in 162 East Dulwich Grove, Dulwich, whence she had moved with Saxl in the 1930s. In the autumn of 1959, having won a place at the Royal College of Art, Kitaj and his wife, Elsi Roessler, and their infant son, Lem, moved from Oxford to 27 Pickwick Road, Dulwich. Thanks to the success of his 1963 Marlborough exhibition, from which Sir John Rothenstein bought Isaac Babel riding with Budyonny (1962) for the Tate, the Kitajs were able to send Lem to the private Dulwich College and move to a larger, detached house around the corner at 131

\footnotetext{
${ }^{21}$ Kitaj, 1963, p. 3.

${ }^{22}$ On Saxl and Bing, see now, McEwan, 2013. Kitaj's early familiarity with matters Warburgian came largely from Wind but in the Marlborough catalogue he credits Lawrence Alloway, principal claimant for the coiner of the term 'Pop Art', 'for bringing to my attention the tradition known as Ut pictura poesis...' As one of his epigraphs to the whole he included: 'as in painting, so it is in poetry. Horace' (Kitaj, 1963, p. 3). Consciousness of another associated figure, Gombrich’s friend and fellow Austrian émigré, Karl Popper, was indicated in his dedication of the catalogue: 'To the Open Society / with reservations'.

${ }^{23}$ Kitaj, 1963, p. 7. An English edition of Warburg's writings was finally published by the Getty Research Institute in 1999 (Warburg, 1999), a fact which Gombrich acknowledges in the second of his Warburg centenary lectures, commenting somewhat ungraciously: 'I only wish the publishers had also had an elementary consideration for readers, for the texts are enshrined in such a heavy volume... I very much regret that obstacle.' Gombrich, 1999, p. 268.
} 
Burbage Road where they remained until 1967. ${ }^{24}$ 'For some reason', he writes in his Confessions:

Dulwich village had attracted Warburg scholars. The very interesting Fritz Saxl, whose Lectures I still dip into 40 years later, lived and died there in leafy refuge from Hitler, as did Gertrude Bing, director of the Warburg Institute in Woburn Square. When I would visit her, she would exclaim: 'But you know so much about us!' as if she belonged to a secret society, which the Warburgers were as far as Modern Art was concerned. I would try to change that and my enemies marked it down in their deathly little notebooks: Kitaj the pretentious, obscurantist exegete. ${ }^{25}$

Kitaj must also have known that his former teacher, the Ruskin Master of Drawing at Oxford, Percy Horton (Fig. 4), together with his wife, Lydia, had lived at 11 Pond Cottages, south of the Picture Gallery in the heart of Dulwich School grounds, their cottage being subsequently acquired by neighbour, James Fitton RA. ${ }^{26}$

Kitaj remembered Horton, who had suffered harsh imprisonment as an 'absolutist' conscientious objector in the First World War as:

'a splendid man [who] created the conditions there in those great old Ashmolean rooms, that I needed most and wanted most... That is to say one was not only able to, but required to work from the figure and could do that every day, all day with minimal interruption from other studies... Horton was a gentle Cézannist who could bear down if needed on rough-hewn American ex-soldiers... from whom he could not tolerate too much neurotic art-jargon or fancy and half-formed modernity in practice. ${ }^{27}$

\footnotetext{
${ }^{24}$ Kitaj, n.d., p. 62. Cf. Livingstone, 2010, p. 21. There is a photograph of the young family outside their first Dulwich home in Pickwick Road taken on 6 December 1962 by Lord Snowdon (NPG) and published in Robertson, Russell, and Snowdon, 1965. The late, great Bryan Robertson was one of Kitaj's early supporters.

${ }^{25}$ Kitaj, n.d., p. 43.

${ }^{26}$ James Fitton, elected RA in 1954, died in his sleep at 10 Pond Cottages on 2 May 1982; Farr, 2004, http://www.oxforddnb.com/view/article/36895, accessed 13 December 2013. In late 1966 he had been runner-up to be President of the RA when Thomas Monnington was elected. Ever conscious of the great tradition, Kitaj writes somewhat inventively in his Confessions, Kitaj, n.d., p. 33, of Horton being a student of Sickert, 'who had been a student of Whistler, who was a student of Lamothe, a pupil of Ingres... and so on.' Sickert's influence on Kitaj, including his iconography, his Warburgian use both of photography and the blank surface of the canvas, has yet to be fully explored.

${ }^{27}$ Kitaj quoted in Barnes, 1982, p. 25.
} 
In his Confessions, Kitaj recalled that it was Horton 'who really turned me on to Cézanne'. ${ }^{28}$ By 'Warburg scholars' the always well-informed Kitaj might also have been thinking of yet another Jewish exile who worked at the Warburg Institute (whose first wife committed suicide as Kitaj's wife, Elsi, would also in 1969), Leopold Ettlinger, who, with his second wife Madeleine, lived in Dulwich during the same period, before permanently migrating to America. ${ }^{29}$ Finally, when in 1967 the Kitajs moved to Berkeley — where he took up a visiting professorship — they sold 131 Burbage Road to Johannes Wilde, the Hungarian-born Michelangelo expert who had left Vienna in 1938 on account of his Jewish wife, Julia. ${ }^{30}$

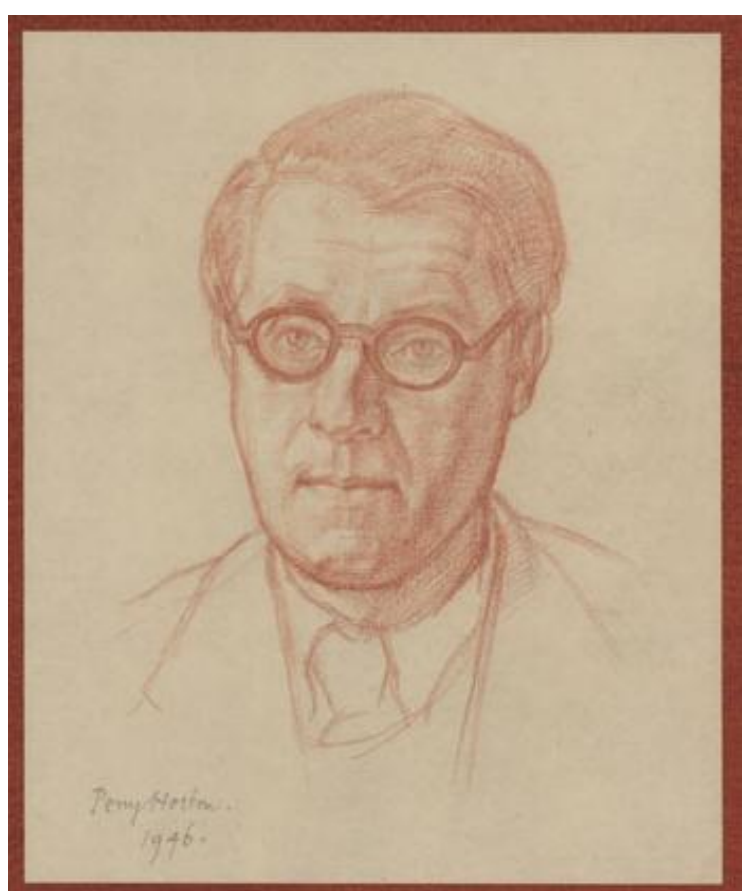

Fig. 4. Percy Horton, Self Portrait, 1946. (Edward Chaney collection.)

Given the fraught state of the relationship between those who ran the Warburg Institute after it settled in London and Edgar Wind, who with Saxl and Bing had been

\footnotetext{
28 'Horton also pointed out Cézanne's roots in Delacroix. He got me to read Kurt Badt's wonderful slim vol. on Delacroix drawings published by Badt's fellow refugee in Oxford, Bruno Cassirer', Kitaj, n.d., p. 33. In an interview with Colin Wiggins, however, Kitaj wrote: 'I don't think I looked carefully at Cézanne until the seventies when a Cézanne madness crept upon me', Kitaj cited in Rudolf and Wiggins, 2002, p. 11.

${ }^{29}$ Information kindly supplied by Elayne Trapp.

${ }^{30}$ Kitaj, n.d., pp. 44, 87. Professor Kerry Downes kindly informs me that Wilde, former deputy director of the Courtauld Institute, had hitherto lived at 4 College Gardens in Dulwich. It is likely that Wilde's former pupil and generous patron, Count Antoine Seilern, paid for both Dulwich houses. Wilde died at 131 Burbage Road less than three months after his wife in September 1970 (Gore, 2004, http://www.oxforddnb.com/view/article/31109, accessed 13 December 2013). Seilern then accommodated another art historian, Fritz Grossmann and his wife, Annie, there when they returned from America in 1972. For more detail, see now Green, 2013, http://www.dulwichsociety.com/2013spring/810-ronald-brooks-kitaj; accessed 28 November 2013.
} 
responsible for relocating it in the early 1930s, and who, with Rudolf Wittkower, founded and edited the first Journal of the Warburg Institute, it is likely that Bing's expression of surprise at Kitaj's knowing so much about them included an element of concern that former deputy director Wind may have prejudiced him against them.

By introducing the young Kitaj to the ideas of Aby Warburg in the spring of 1957, soon after he arrived in Oxford, Wind no doubt communicated to him something of his sense of ownership over Warburg's legacy and a corresponding sense of exclusion from the Institute in its post-war manifestation. ${ }^{31}$ Kitaj wrote that he had known the writings of Erwin Panofsky before he arrived in England, owning in particular a copy of Panofsky's Dürer since his teens, so he would to some extent have been prepared for the inspiring lectures of Wind, who had been Panofsky's first $\mathrm{PhD}$ student. Although Panofsky had studied with Warburg, and in his obituary declared that he had opened up 'a new Kingdom' in the study of art, ${ }^{32}$ it was Wind who introduced Kitaj to the ideas of their master. ${ }^{33}$ Remembering this period Kitaj wrote:

Iconological studies had caught my interest by the time I was eighteen or so in New York. I had read into Panofsky long before I heard of Wind. You see, it was the weirdness, the unfamiliar ring of so much of the 'art' they would use to illustrate their theses... these studies, with their fabulous visual models and sources in ancient engravings, broadsheets, emblem-books, incunabula, were like buried treasure! ... So - one of the first turn-ons had been purely visual... appropriate, after all, for a painter... But, of course, there were, for me, ideological discoveries in those obscure readings... It dawned on me that here were people who had spent their lives reconnecting pictures to the worlds from which they came. ${ }^{34}$

\footnotetext{
${ }^{31}$ Kitaj came to Britain for the first time in early December 1956 to register at the Ruskin School. He then returned to Fontainebleau to complete his military service and then, while Elsi went back to her parents in Ohio for Christmas, he drove alone up through Northern France, crossed the Channel and began the Fine Art course, supplemented by History of Art, for which he received a commendation, and Anatomy, which he merely passed. I thank Dobrochna Futro, of the Ruskin School, for forwarding an image of the registration card to me and Mark Hathaway for responding to my questions.

32 Obituary in the Hamburger Fremdenblatt, 28 October 1929, quoted in Wind, 1983, p. 10.

${ }^{33}$ For Gombrich's relationship with Panofsky, see McGrath, 2014. When I arrived at the Warburg in 1975 as a would-be iconographer keen to interpret Velazquez's Rokeby Venus as an image of Divine Love/Truth seen through a glass darkly, Gombrich was very dismissive of my appeal to Panofsky as corroborative support and indeed of his work more generally.

${ }^{34}$ Livingstone, 2010, p. 15. Michael Baxandall would coin the concept of the 'period eye' which describes what Kitaj is concerned with here; see below, note 55.
} 
In 1937, Wind contributed an article to the first issue of The Journal of the Warburg Institute entitled 'The Maenad under the Cross' in his most Warburgian mode. He begins by quoting 'perhaps the shrewdest advice Sir Joshua Reynolds gave his students... that they should take hints from ancient masters and employ them "in a situation totally different from that in which they were originally employed".' In expounding this rule, Wind writes, Reynolds hit upon: 'a fundamental law of human expression.' He follows this with Reynolds' example (in the artist's own words) of:

...a figure of a Bacchante leaning backward, her head thrown quite behind her, which seems to be a favourite invention, as it is so frequently repeated in basso-relievos, cameos and intaglios; it is intended to express an enthusiastic frantic kind of joy. This figure Baccio Bandinelli, in a drawing that I have of that Master, of the Descent of the Cross, has adopted... for one of the Maries, to express frantic agony of grief. It is curious to observe, and it is certainly true, that the extremes of contrary passions are with very little variation expressed by the same action. ${ }^{35}$

Wind continues to explain that:

Some time ago, the late A. Warburg, without knowing of this passage in Reynolds' Discourses... collected material which tended to show that similar gestures can assume opposite meanings. The pagan figure of the dancing maenad was the central theme of these studies, and their most poignant chapter contained the story of how Bertoldo di Giovanni, the early Renaissance sculptor, transformed the maenad into a Mary Magdalene moaning under the Cross. ${ }^{36}$

It may have been this article that inspired Kitaj to depict Warburg as a Maenad (1961-2, Fig. 6), on whose cubic head is placed a cowboy hat based on that worn by

\footnotetext{
${ }^{35}$ Wind, 1937, pp. 70-71; reprinted in slightly revised form in Wind, 1986, pp. 74-80. This article was one of five that Wind contributed to the first Warburg Journal, the young Ernst Gombrich contributing a piece on Michelangelo's Sacrifice of Noah.

${ }^{36}$ Dr Ben Thomas, author of Oxford Dictionary of National Biography entry on Wind, (having listened more attentively than I to a talk by Carlo Ginzburg) kindly points out that Warburg may in fact have known the Reynolds observation as it had appeared in Darwin's The Expression of the Emotions in Man and Animals, which he knew well as a principal source for his 'pathos formula'. Gombrich quotes Warburg's enthusiasm for the German translation which also appeared in 1872: 'At last a book that helps me,' Gombrich, 1999, p. 271.
} 
Warburg in the now well-known 1896 photograph in which he poses alongside and holds the arm of a Hopi dancer in Oraibi, Arizona (Fig. 5). ${ }^{37}$

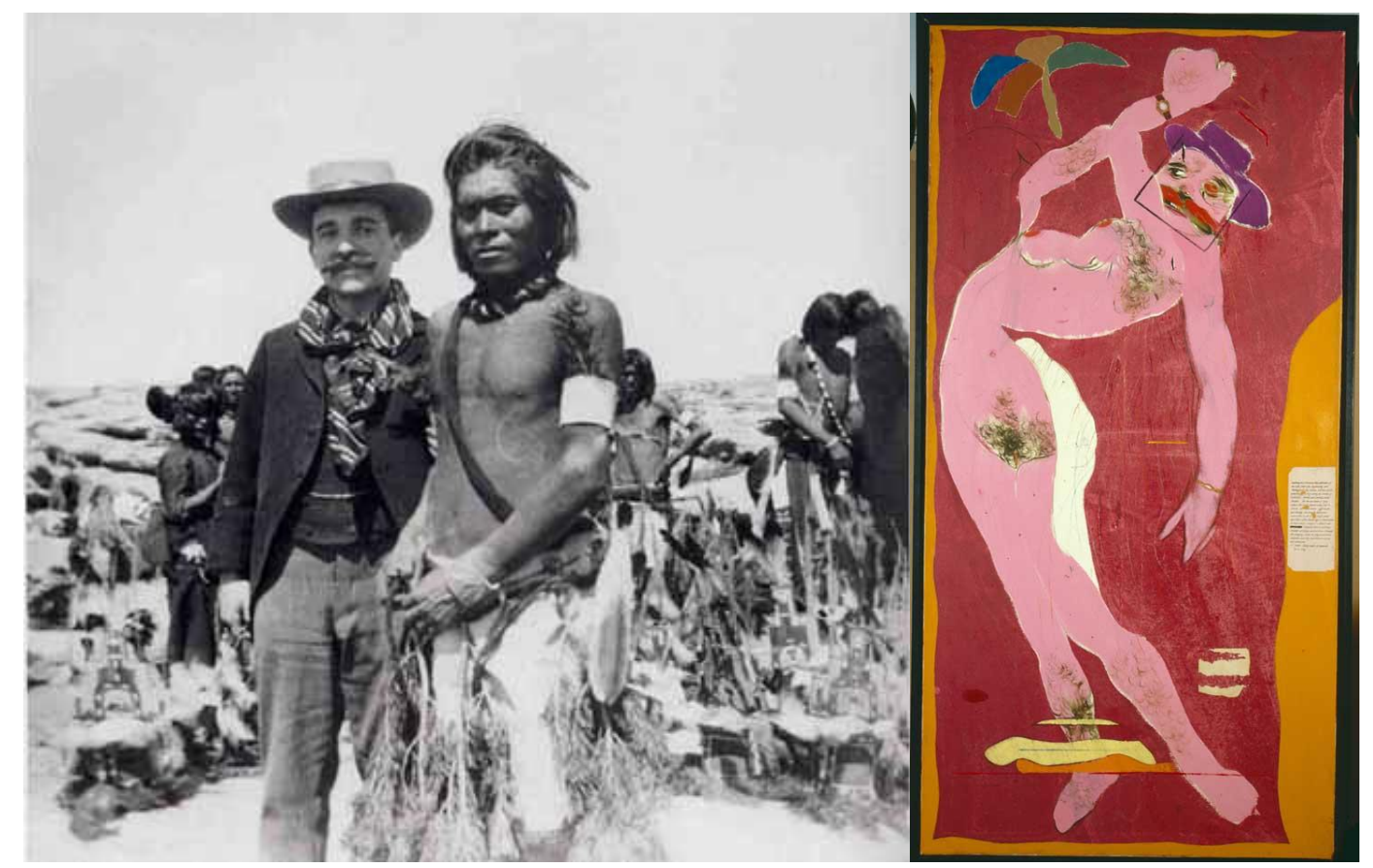

Figs. 5; 6. Warburg with Hopi Indian, 1895, and R.B. Kitaj, Warburg as a Maenad, 1961-2. (Courtesy Kitaj Estate.)

Certainly the Maenad motif inspired the disturbing figure to the right of the major picture he did in the wake of his 1963 success at the Marlborough Gallery, The Ohio Gang (1964; purchased by Alfred Barr for the Museum of Modern Art, New York). In one of those detailed commentaries that the Tate perhaps injudiciously encouraged him to write for his 1994 'Retrospective', Kitaj explained: 'I was still under the Warburg spell in those early sixties and the Maenad-Nanny at the right is a memory of those pre-Christian wraiths the Warburgers detected at the base of crucifixions in art.' Then, illustrating the way in which he brought together the ancient or archetypal with the profoundly personal in his pictures, he continues:

She is pushing a homunculus-manikin because I'd just bought a pram for a second child, who died at birth as I began this painting. ${ }^{38}$

\footnotetext{
${ }^{37}$ Cestelli Guidi and Mann, 1998, fig. 80. Opposite this image in the book, Warburg poses alone, having replaced his hat with a Hemis Kachina mask.

${ }^{38}$ Kitaj, 1994, p. 84. In his Confessions (Kitaj, unp., p. 64) Kitaj elaborates on how he and Elsi adopted their Bengali daughter, Dominie, through the Church Adoption Society in Holborn as a result of the 'loss of a little girl at birth'.
} 
From the second Journal, dated 1938-9, it appears Kitaj derived his images of an obelisk and monument to Frederick the Great which illustrate Alfred Neumeyer's article on 'Monuments to 'Genius' in German Classicism' for The Murder of Rosa Luxemburg (1960) (Fig. 7). ${ }^{39}$ Wittkower's 1942 article on 'Marvels of the East' in volume V of the Journal inspired motifs in several of Kitaj's other early pictures, including his Pariah of 1960 and two 1962 images, Welcome every Dread Delight and the Isaac Babel, now in the Tate Britain. ${ }^{40}$ That he subscribed to the Journals as they appeared is indicated by the fact that he also used the surreal medieval figure of the silenced 'Nobody' from an article by Gerda Calman in the 1960 Journal in two of his pictures dating from the following year. ${ }^{41}$

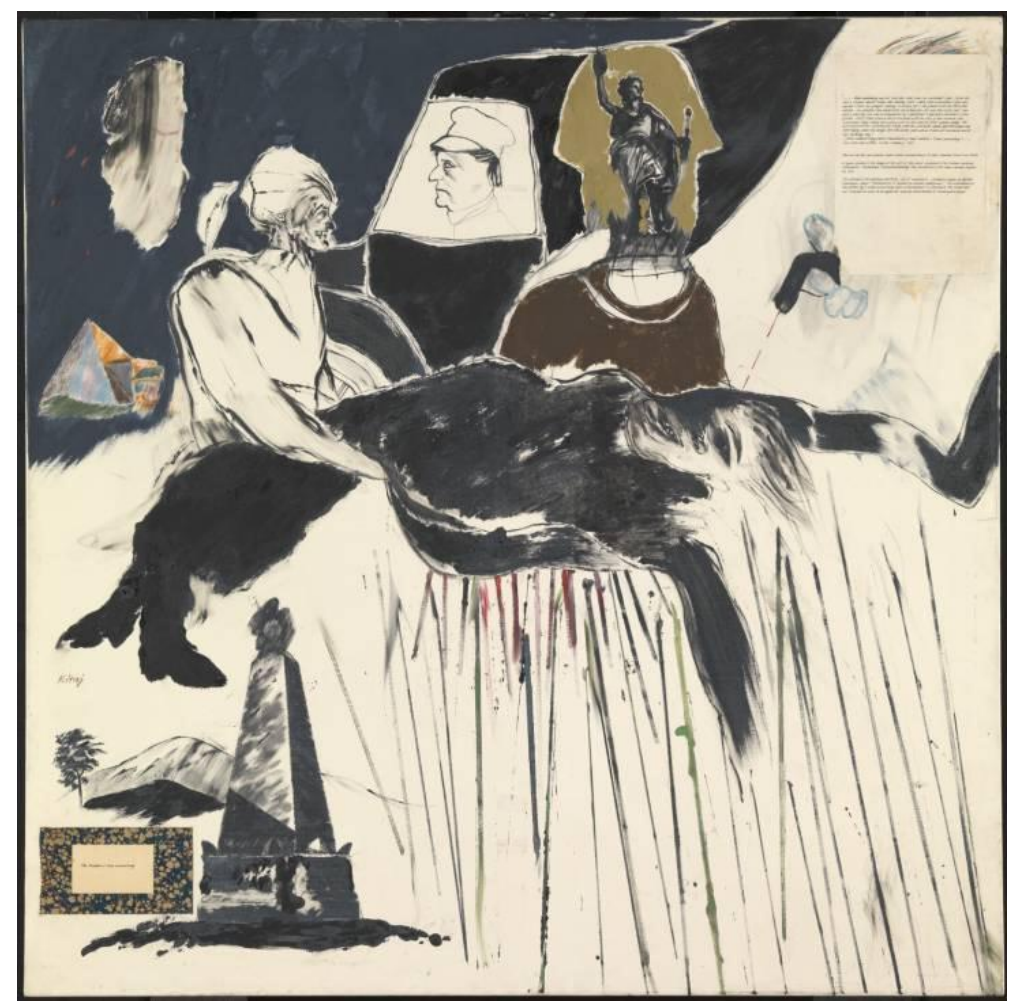

Fig. 7. R.B. Kitaj, The Murder of Rosa Luxemburg, 1960. (Courtesy Kitaj Estate.)

Meanwhile, after a few more or less unsalaried years at the Warburg Institute, in 1939 Wind had left London for America, promoting the Warburg project there. Once war was declared he prepared for the possibility that the Institute would relocate to America to preserve it from bombing, but partly because of the subsequent threat of U-boats it was instead relocated to the Lea in Denham, South Buckinghamshire, most

\footnotetext{
${ }^{39}$ Neumeyer, 1938.

${ }^{40}$ Wittkower, 1942.

${ }^{41}$ Calman, 1960; cf. Livingstone, 2010, pp. 15-16.
} 
of the books meanwhile being stored at the Watts Gallery near Guildford, Wind lending some of his to replace them. ${ }^{42}$ From surviving correspondence it becomes clear that although some felt that Wind deserted the Institute, he had been expected to succeed Saxl as director. Disagreements regarding teaching methods, relative status and salaries followed, however, and by the time Saxl died in 1948, Bing proposed that Henri Frankfort should be appointed instead. ${ }^{43}$ When Frankfort unexpectedly died in 1954, Wind offered his services but Bing's response was lukewarm and a few weeks later it emerged that she herself would succeed. Bing was in turn succeeded at her retirement in 1959 by Gombrich who had hitherto been her assistant in charge of publishing Warburg's papers. ${ }^{44}$ By this time Wind had left Smith College in Massachusetts and returned to England as Professor of Fine Art at Oxford where he remained until his retirement in 1967 . He was already suffering from leukaemia and died in London in 1971. ${ }^{45}$

A surviving note dating from the late 1950s among the Wind Papers in Oxford suggests that Wind not only influenced Kitaj's approach to the history of visual culture but also provided advice on his drawing to complement that received from Percy Horton:

Dear Professor Wind

A few weeks ago you suggested that you would have time to examine some drawings of mine after the end of term. Wise counsel would be most welcome should you find time.

With thanks,

Ronald Brooks Kitaj

\footnotetext{
${ }^{42}$ I am very grateful to Ben Thomas for a copy of his unpublished lecture: ‘An Art Historian's Dilemma', which makes it clear that Wind's negotiations in America strengthened Saxl's hand in negotiating the Warburg's incorporation into the University of London (Thomas, 2009); cf. now McKewan 2013, passim. On 26 June 1948 Wind complained to Bing that some of his books had gone missing and also that Saxl and Wittkower's publication: British Art and the Mediterranean (1948) contained inadequate acknowledgement to his work; see the correspondence in the Walter Friedlaender Collection, LBI, AR 3393, http://www.archive.org/stream/walterfriedlaender_01_reel01\#page/n801/mode/1up; accessed 11 December 2013. I thank Elizabeth McGrath for this reference.

${ }^{43}$ Frankfort, 2004, http://www.oxforddnb.com/view/article/31887, accessed 13 December 2013, on Bing; cf. Thomas, 2009, n.p.

${ }^{44}$ Wind's awkwardly-worded letter (in English) and a copy of Bing's somewhat disingenuous reply are in the Warburg Archive, Woburn Square.

${ }^{45}$ A room in the Sackler Library in Oxford is named after him.
} 
c/o Ruskin School. ${ }^{46}$

Decades later, in November 1993, when preparing for his fateful Tate retrospective, Kitaj wrote to Wind's devoted widow, Margaret, asking for a photograph of him to include in the catalogue:

30 years ago when I was a young art student in Oxford, Edgar Wind was very kind to me and he had a very great influence on me. ${ }^{47}$

Margaret Wind replied: 'still vivid in my memory is your visit to Belsyre Court one afternoon many years ago.' This is complemented by Kitaj in his Confessions: 'The great Edgar Wind also befriended me to my amazement and even had me to tea in his North Oxford flat. ${ }^{48}$ Enlarging on this theme Kitaj writes:

Oxford had just given its first chair in Fine Art to the brilliant, contentious refugee Edgar Wind, whose popularity was such that his amazing lectures, on Italian Renaissance mainly, were given at the Playhouse, across the street from my Ashmolean. This was my first encounter with the world of Wind's master Aby Warburg. This new/old world seemed to my surrealist-inclined mind, an interesting parallel river to the important, and dominant one called art for art's sake, which ran at floodtide through the School of New York and to a lesser degree through the School of Paris, Picasso-Matisse oriented as it was, not abstract... I became aware that Warburg was to art history what Einstein was to physics, Wittgenstein to philosophy, Freud to the study of the mind, Eisenstein to film and so on: Jewish founding fathers of Modernism. Warburg was the prophet of Iconology and its child, iconography, as another Jew, Berenson had been the prophet of the more familiar art-historical persuasion called, I guess, connoisseurship. Both Jewish-induced art histories would interest me greatly. ${ }^{49}$

\footnotetext{
${ }^{46}$ Special Collections, Bodleian Library,Wind Box 49 [III, 6, vii]. I am very grateful to Ben Thomas for this reference. There is much other evidence of Wind's continued interest in Kitaj's career in the form of clippings, including Michael Podro's 1979 Art International article and Marco Livingstone's in the July 1980 edition of Burlington Magazine. Interestingly there is also a cutting of Marina Vaizey's enthusiastic review of the 1963 Marlborough show, as there is in the Kitaj archive; she was nevertheless one of the severest critics of Kitaj's later work.

${ }^{47}$ Letter dated November 1993 in the same box of Wind Papers.

${ }^{48}$ Kitaj, n.d., p. 40 and copy of Margaret Wind's reply: Wind Papers, Special Collections, Bodleian Library,Wind Box 49 [III, 6, vii]. The first Mrs Wind was a personal friend of Warburg's.

${ }^{49}$ Kitaj, n.d., p. 35. Kitaj restates this more emphatically in his Second Diasporist Manifesto (Kitaj, 2007), no. 118 .
} 
Fondly remembering Oxford's second-hand bookshops Kitaj writes:

My greatest scoop was a full set of Warburg Journals from their London inception (1937) to date. These journals describe a stunning face of the Jewish Diaspora in one of its grandest moments, its golden decades, an amidah (standing up to) Hitlerism. The amazing 'visuals', plates I mean culled from Warburgian libraries of fantastical imagery, sparked the always latent Surrealist-Dadaist in me and always will. My Warburgers command pride of place in my innermost $21^{\text {st }}$ sanctum - My Jewish library-room at home in Los Angeles, Los Angeles Judios [sic]. ${ }^{50}$

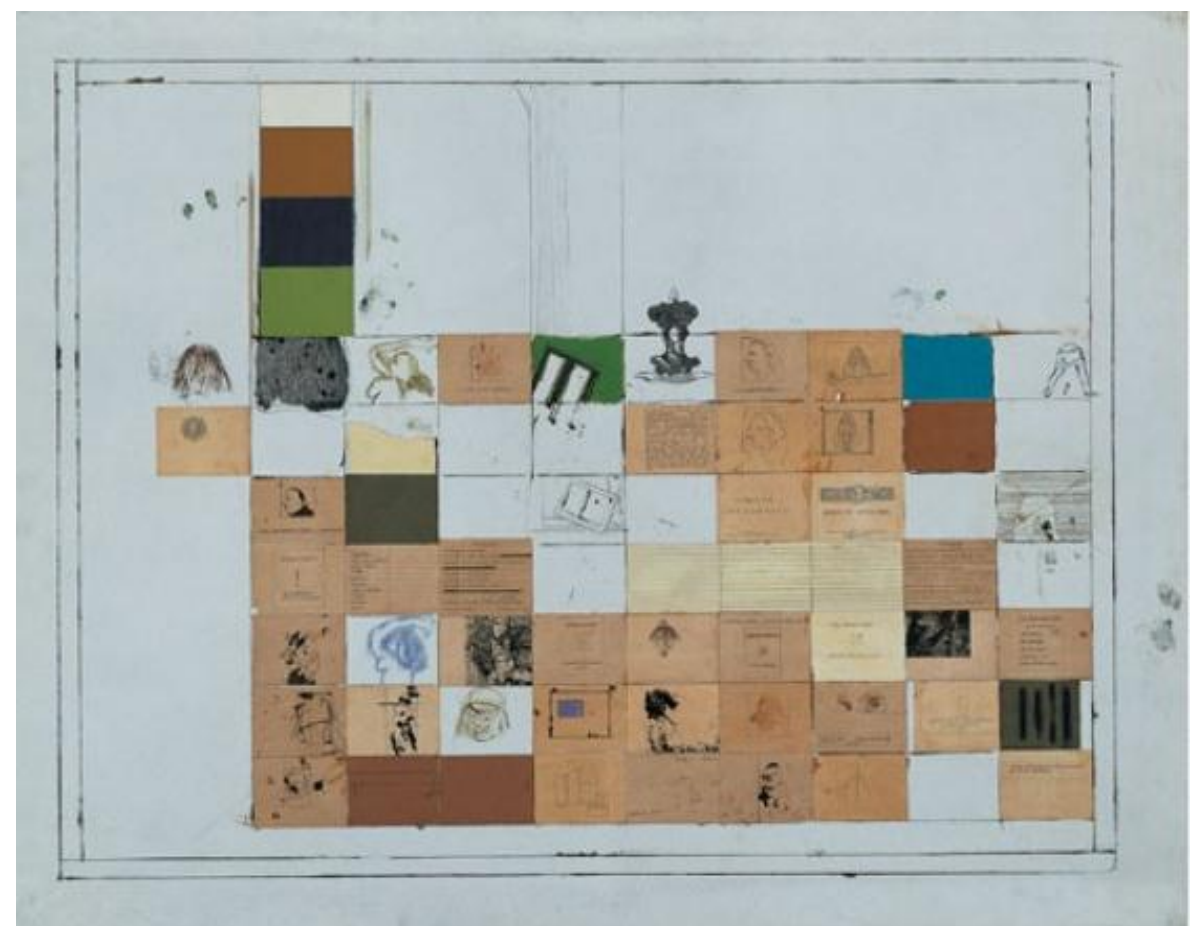

Fig. 8. R.B. Kitaj, Specimen Musings of a Democrat, 1961. (Pallant House Gallery, Chichester.)

This confirms that Warburg and his foundation remained at the core both of Kitaj's art and of his ever-enlarging interest in Jewishness. In 1980 he based his Jewish School (Drawing a Golem), in which one of the children draws the magical figure perhaps too late for it to come to life and save them, on an anti-Semitic nineteenth-century German watercolour published by Isaiah Shachar in his Warburg Institute Survey on The Judensau: a Medieval anti-Jewish Motif and its History. ${ }^{51}$ Conversely, his

\footnotetext{
${ }^{50}$ Kitaj n.d., p. 38. See also Kitaj, 1994, p. 215.

${ }^{51}$ Shachar, 1974. Morphet (Kitaj, 1994, p. 138-9) transcribes a commentary by Kitaj in which he misspells Shachar's name as (the more-Jewish seeming?) 'Schachar' which Livingstone (Livingstone, 2010 , p. 36), illustrating the image, takes still further from the original as 'Schacher'. Isaiah Shachar
} 
interest included non-Jewish contributors to the Warburgian project, notably Frances Yates, whose illustrated articles on the Catalan mystic, Ramon Lull, had already inspired some of the iconography in Specimen Musings of a Democrat of 1961 shown in his 1963 Marlborough exhibition (Fig. 8). ${ }^{52}$ The format of this early oil and collage, now part of the Wilson Gift in Pallant House, Chichester, is at the same time one of Kitaj's works most obviously influenced by Warburg's fascinating Mnemosyne-Atlas, which in itself could be seen as transitional between an aid to art history and a work of art in itself. In the same year, Kitaj re-cycled motifs from this in a quite different picture also now at Pallant House, Priest, Deckchair and Distraught Woman. ${ }^{53}$ Finally it is poignant to note in one of the photographs that Christie's commissioned to illustrate the 2008 sale catalogue of The Collection of R.B. Kitaj a copy of Michael Baxandall's Giotto and the Orators, nestling among his books, perhaps 'the Giotto book' he says he went to bed with at 8pm one night during the time he was painting the wonderful, Giotto-derived Los Angeles No. 17 (Zip), 2002 (Fig. 9). Kitaj's source for this painting was the fresco in the Arena Chapel in Padua of Saints Anne and Joachim embracing outside the Temple (Fig. 10). ${ }^{54}$ Michael Baxandall was a year younger than Kitaj and died a year after him as a fellow-sufferer from Parkinson's disease. Gertrud Bing gave him a job in the Warburg Institute photo collection in 1958, at around the time Kitaj acquired his complete run of the Journals. Supervised by Gombrich for a $\mathrm{PhD}$ he never completed, Baxandall taught at the Warburg from 1965, however, and was given a chair in 1981, remaining closely associated with the Institute to the end, though latterly also spending much of his time in California. ${ }^{55}$

\footnotetext{
was an Israeli-born scholar whose $\mathrm{PhD}$ was supervised by Gombrich at the Warburg Institute in the mid-1960s. He died aged only 42 in 1977. A posthumous volume of his writings entitled The Visual Dimension: Aspects of Jewish Art was published by Clare More in 1993. See Shachar, 1993.

${ }^{52}$ It is worth noting that even Yates was introduced to the Warburg Institute by Edgar Wind (c. 1936), a fact acknowledged by Gombrich in his only reference to Wind in Tributes; see Gombrich, 1984b, p. 212. According to correspondence with Saxl in the Warburg Archives, Wind subsequently felt that Yates also failed to acknowledge him sufficiently.

${ }^{53}$ See Churchill, Guy, Martin, and van Raay, 2004, p. 111.

${ }^{54}$ Kitaj, unp., p. 176. Illustrated as plate no. 241 in Livingstone, 2010, p. 253; cf. Christie's, 2008, p. 32. Adjacent to Baxandall's book in this photograph is Giotto: The Arena Chapel Frescoes, ed. James Stubblebine, which illustrates this image (in later editions on the front cover), Stubblebine, 1996. For Kitaj's reference to this depiction of 'Christ's Jewish grandparents' see Lambirth, 2004, p. 80.

${ }^{55}$ See the obituaries, McGrath, 2008, http://www.theguardian.com/artanddesign/2008/aug/26/historyandhistoryofart; accessed 28 November 2013; Onians, 2011.
} 


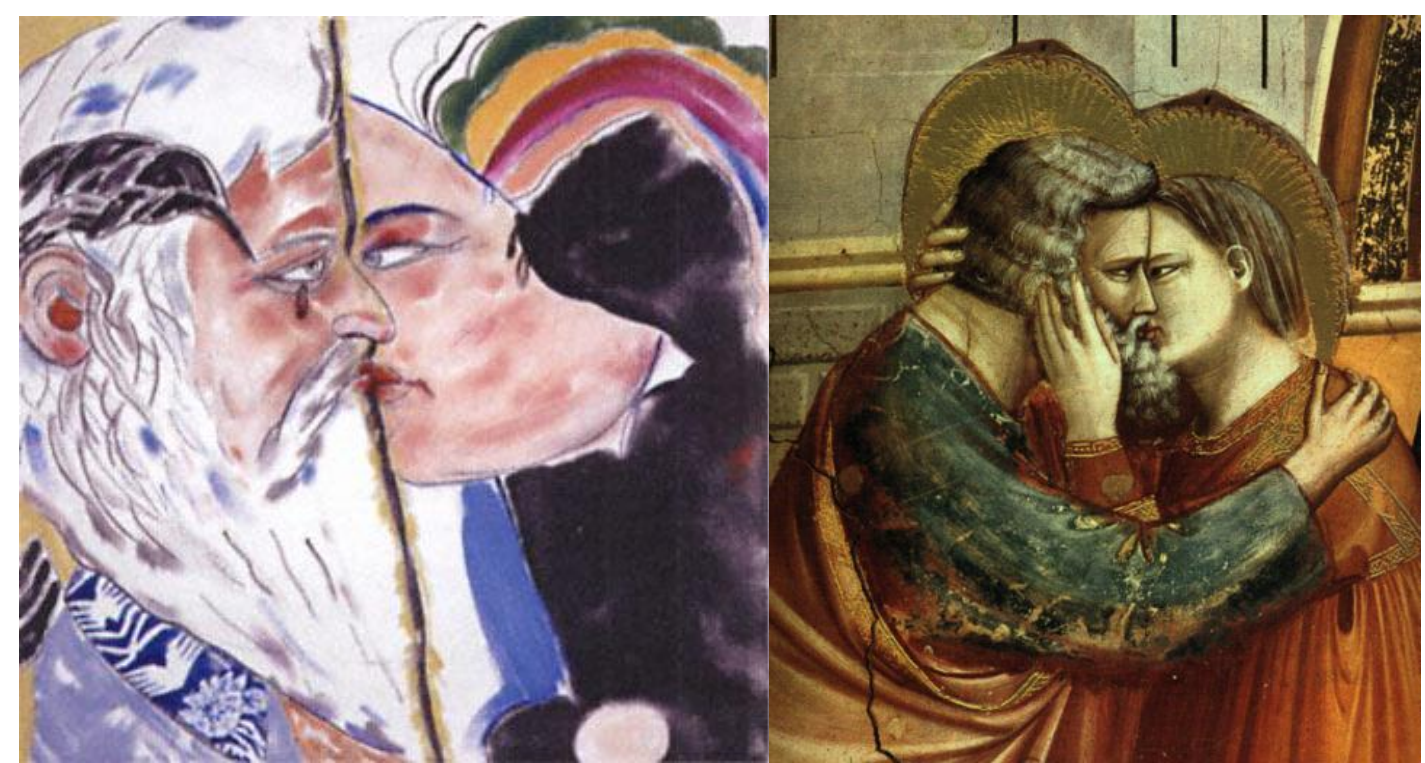

Figs. 8; 9. R.B. Kitaj, Los Angeles No. 17 (Zip), 2002 (courtesy Kitaj Estate) and Giotto, Arena Chapel Frescoes (detail), ca. 1305. (Scrovegni Chapel, Padua.)

In the works of his final decade, as an exceptionally literate artist (and a greater critic than his critics), Kitaj continued to reference his Warburgian cultural memorials but now combined these with powerful expressions of yearning for a more recent past in the form of his relationship with his second wife Sandra Fisher, whose sudden death he blamed on the malicious reception of his Tate retrospective. Although rich iconographical sources still underpin his Los Angeles series - the very title referencing both place and subject - he no longer laboured to explain them in detail. He returned instead to the philosopher who had encouraged both him and Warburg to treat the Dionysian and Apollonian with equivalent high seriousness. As Warburg returned to Nietzsche's Birth of Tragedy when revisiting the subject of Dürer in the 1920s, so Kitaj reminds us that "Nietzsche called tragedy "the supreme art in the affirmation of life", ,56

But even after what he eventually suffered with the loss of his wife, and despite - but also thanks to - his ever-evolving identification with both racial and religious Jewishness (he married Sandra in the Synagogue), Kitaj maintained a sense of humour, often at his own expense. He kept a photograph of Ezra Pound on his studio

\footnotetext{
${ }^{56}$ Kitaj, 2003, p. 10; cf. Livingstone, 2010, p. 254. For Warburg's critique of Nietzsche in 1905, however, see Warburg, 1999, p. 544.
} 
wall, referring to him as 'my favourite anti-semite. ${ }^{57}$ He remained similarly loyal to T.S. Eliot, refusing to join those who accused him (or Wyndham Lewis) of antiSemitism, rebelling instead against the aesthetic of artistic anonymity: 'against my snooty countryman-of-genius, Eliot, I love personality in art', citing as exemplary that other great writer-artist, Van Gogh, who 'said he loves the man, then the art.' Before he definitively left London for Los Angeles he went on one last visit to a Dutch brothel, concluding that 'the only thing I'll miss about England is Holland. ${ }^{58}$ Perhaps indicative of more than mere stoicism was the extent to which, in contrast to Cézanne, who ended his friendship with Emile Zola when he read the latter's portrayal of him as the eventually suicidal painter, Claude Lantier, in L'Oeuvre, Kitaj seemed to accept and even commend Philip Roth's darkly comic recreation of him as the lecherous puppeteer in Sabbath's Theater in 1995. His novelist friend (and fellow Nietzschean) even felt licensed to return to the theme of the marginalized man who blames the death of his painter wife on his persecution by the establishment in The Human Stain. ${ }^{59}$ Albeit poignantly, a sense of humour survives even in Kitaj's late, great paintings of him and Sandra; those in which he depicts himself as the slightly absurd, much older and smaller, white-bearded but still sexually-charged man, embracing the beautiful, voluptuously serene young Sandra, as Shekinah, the Kabbalah's female aspect of God. ${ }^{60}$ In Los Angeles No. 13 (2002) the two of them are pushing an oldfashioned pram with a Hockneyesque child in it reminiscent of the ensemble pushed by a Warburgian Maenad four decades earlier in the Ohio Gang.

\footnotetext{
${ }^{57}$ Or more picturesquely, referring to his 'PoundEliot libery' (sic) as: 'favorite Antisemite motherfuckers' (Kitaj, n.d., p. 284). In 1977 Kitaj wrote that he sometimes thought he 'would be further on in my maturity as a painter if I had been as moved by Rembrandt when I was eighteen as I was by Pound.' Kitaj, 1977, pp. 75-7.

${ }^{58}$ Kitaj, n.p., p. 256. He had meanwhile, however, had an affair with and, in his own words, 'agreed to marry' Susannah Pollen, who had a son with him named Hougharry (Hoagy); the latter's step-father, Seth Stein, eventually brought him to Los Angeles to meet his father; cf. McCully, Raeburn, Watson, 2011, p. 81. Supplemented with information kindly supplied by Susannah Pollen. Kitaj's version of events is told briefly in Kitaj, n.p., p. 229. A 1999 painting of Susannah Pollen is currently (2013) on the market with Stephanie Moeller, Berlin.

${ }^{59}$ Livingstone, 2010, p. 259. I thank Tracy Bartley for informing me that when she arrived to work for Kitaj in Los Angeles he gave her a copy of Sabbath's Theater and suggested she read it as a way of 'getting to know him' (Bartley, 2013). Roth, 1995; Roth, 2000.

${ }^{60}$ Kitaj's source for his knowledge of this was principally Gershom Scholem's On the Mystical Shape of the Godhead. 'I assume it to be the key modern text on Shekhina, or very nearly so. It is bewilderingly magical (literally) and overwhelming in a, to me, inspirational way. The Shekhina concept appeared in my Yellow Studio after I had done over 20 paintings called Los Angeles, about Sandra and me, what I have called the Woman-Man Question...' (Kitaj, n.p., [14 December 2003], p. 310). Kitaj was also greatly influenced by (and painted) the Talmud scholar Rabbi Adin Steinsaltz who inspired his Biblical Portraits series of prints; see Michal Friedlander, 'The Skeptical God-Seeker,' in Kugelmann, Gillen, Gaßner, 2012, pp. 190-91, and Ramkalawon, 2013, pp. 213-25.
} 
Though still not in favour with the mainstream critics, these paintings will, I believe, come to be recognized as the magnificent culmination of Kitaj's career, equivalent in his oeuvre not only to the 'old-age-style', non-finito works of Titian, Goya, Degas, Cézanne, Matisse, Bonnard and his other artistic heroes but to Thomas Hardy's late, poignant poems of guilt and mourning written after the sudden death of his first wife or the equivalently cathartic 'sorrow work' in Mahler, or Proust's recollections of lost time. ${ }^{61}$ Like these, Kitaj had spent a lifetime honing his artistic medium in which he could now express his grief and longing with the extraordinary fluency and 'unity of style' advocated by Kenneth Clark. ${ }^{62}$ He no longer needed to explain his symbolism for his medium merged seamlessly with his message and his dreams were at last fulfilled in art rather than life. ${ }^{63}$ His extraordinary visual and intellectual literacy and his life-long aspiration to be part of the great tradition finally come together in this series of portrayals, not of a mountain, a la Cézanne, nor of depressingly isolated individuals (even when depicted alongside others) a la Lucian Freud, whose victims lie on beds or sofas like analysands in his grandfather's consulting room, ${ }^{64}$ but rather in intense communion with each other, in what, politely preferring his own artistic vision to Freud's, Kitaj calls: 'the greatest story ever told, the Woman-Man Story.' Contextualising his credo in echoing Nietzsche's reminder of the relationship between

\footnotetext{
${ }^{61}$ One of his last pictures was of the young Proust (reproduced in Livingstone, 2010, cat. no. 963). Sydney Schiff, completer of the translation of A la Recherche (and patron of an ungrateful Wyndham Lewis) tried (unsuccessfully) to get Picasso to paint a portrait of Proust (Richardson, 2008, p. 207). For Kitaj on Hardy see the preface to the 1984 edition of Livingstone's monograph reprinted in the $4^{\text {th }}$ ed.; Livingstone, 2010, pp. 230-31. Latterly he claimed his favourite poet to have been Emily Dickinson, no doubt partly due to Sandra's enthusiasm for her work. His copy of her poems had been Sandra's and 'lies by my easel. You may see "White Exploit" written in some of these blank spaces', he writes, comparing Dickinson's term for death with the 'bare white canvas' he left in his last pictures; Rudolf and Wiggins, 2002, p. 26. Kitaj began a series of prints entitled Mahler Becomes Politics, Beisbol in 1964 and published his essay: 'Mahler: A Celebration and a Crutch' the following year in the catalogue to his New York exhibition; see Kinsman, 1994, pp. 27-28; cf. Ramkalawon, 2013, pp. 37-77.

${ }^{62}$ Clark, 1982, pp. 174-5. Kitaj seems to have begun self-consciously working on the 'old-age style' he discusses with Richard Wollheim in 1992 (probably echoing Clark's use of the phrase) three years after his heart attack; see Kitaj, 1994, p. 42; cf. Rosen, 2009, p. 93.

${ }^{63}$ Marco Livingstone tells of him kissing a painting of Sandra he had begun when she was still alive (Livingstone, 2010, p. 57), inevitably reminding one of Pygmalion kissing the ivory Galatea, or indeed of the related final scene in Shakespeare's Winter's Tale in which the painted statue of Hermione comes to life and embraces Leontes after he says 'I will kiss her.' In Rudolf and Wiggins, 2002 p. 43, Kitaj confesses/boasts of kissing Cézanne’s Bathers and Degas' Spartans, when he was preparing the National Gallery exhibition.

${ }^{64}$ Chaney, 2006, pp. 39-74.
} 
creativity and the truism that 'procreation depends on the duality of the two sexes', Kitaj writes that this 'Story':

has become quite rare in painting since the death of Picasso... My Sandra was an exception. She often painted nude men and women embracing. Her example has been a major influence on me. So I've done about 20 of these love stories so far, and our romance need not die. ${ }^{65}$

In view of what he says here it is especially appropriate that in one of the finest examples in the series, Los Angeles No. 22 (Painting-Drawing), of 2001 (Fig. 11), Kitaj depicts himself with his by now much younger wife seated on his lap who is recording the outline of the shadow behind him.

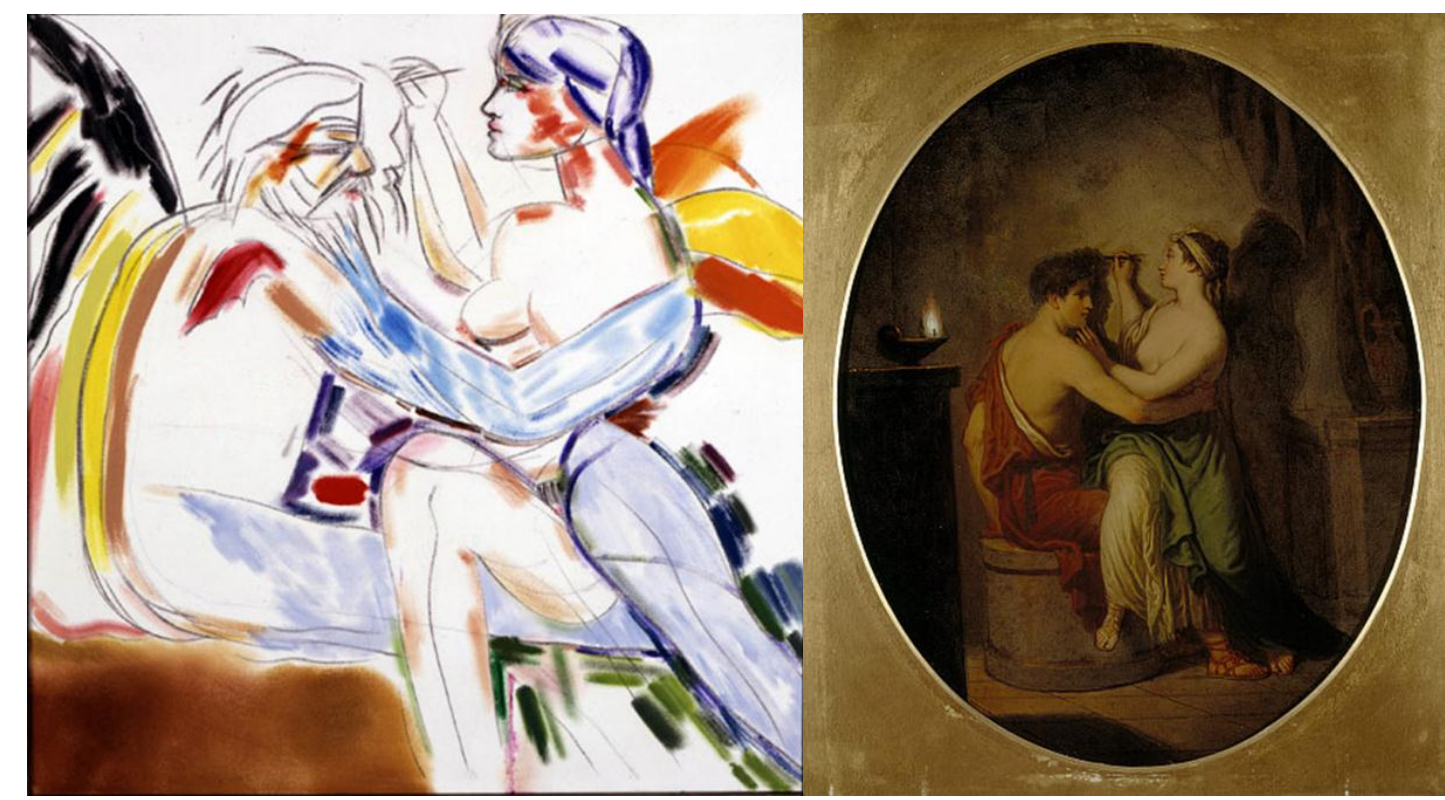

Figs. 11; 12. R.B. Kitaj, Los Angeles No. 22 (Painting-Drawing), 2001, (Marlborough Fine Art) and David Allan, The Origin of Painting (The Maid of Corinth), 1775. Oil on panel, 51.5 x $44.1 \mathrm{~cm}$, Edinburgh, Scottish National Gallery, NG612. (Scottish National Gallery.)

Still reflecting his commitment to the Warburgian Nachleben der Antike, this symbolic image is clearly based on the ancient account of the invention of art, the story of how a potter's daughter from Corinth drew her lover's shadow on the wall as a record before he departed for far-flung places. ${ }^{66}$ In particular, Kitaj surely based his magnificent creation on a popular eighteenth-century picture, The Origin of Painting,

\footnotetext{
${ }^{65}$ Kitaj, 2003, p. 10. In fact, Kitaj was not thinking exclusively in terms of heterosexuality as, together with the homosexual painter Adrian Berg, he encouraged David Hockney to paint his private life and loves and in particular his relationship with his Jewish boyfriend, Peter Schlesinger.

${ }^{66}$ Cf. Pliny the Elder, Natural History, XXV, cap. 3 (the story was also elaborated by later authors).
} 
done in Italy in 1775 by the Scottish painter David Allan (Fig. 12). Even this picture, which normally hangs in the National Gallery of Scotland, would in Kitaj's mind have had a Warburgian provenance for he very likely saw it when it featured in Gombrich's National Gallery of London exhibition and accompanying publication entitled Shadows: The Depiction of Cast Shadows in Western Art. ${ }^{67}$ Both appeared in April 1995, six months after the closure of Kitaj's Tate retrospective (which included Gombrich's portrait) and Sandra's death, but two years before he left England for Los Angeles. ${ }^{68}$

Just as fellow-autodidact Wyndham Lewis's early familiarity with Cubism underpinned the later, more figurative style he evolved in defiance of his selfconsciously avant-garde contemporaries, so Kitaj's pioneering Warburgianism (and pre-Bergerian Benjaminism) encouraged him to reject the mere art-for-art's sake formalism, which Hegel anticipated and Wind's Reith Lectures condemned in Baudelairian terms as 'this destructive tolerance [which] would one day be hailed as a form of "progress".' As if anticipating the kind of art that is selected to represent twenty-first-century art in Tate Modern and increasingly in Tate Britain and now even in the National Gallery, Wind continues:

In this complacent receptacle, a friendly abyss, the anarchic energies of creation would be soaked up into nothing. ${ }^{69}$

There may be an echo here of Wyndham Lewis's chapter heading in The Demon of Progress in the Arts: "There is a Limit, beyond which there is Nothing. ${ }^{70}$ In a letter dating from October 1972, Kitaj wrote that he owned 'a whole shelf of Wyndham Lewis... I haven't read into Lewis in many years but I was very moved by him - I

\footnotetext{
${ }^{67}$ Gombrich, 1995.

${ }^{68}$ Other versions of Allan's popular picture, which was also engraved, are discussed in SanchezJauregui and Wilcox, 2012, pp. 286-7.

${ }^{69}$ Wind, 1964, p. 101.

${ }^{70}$ Chaney, 1990, pp. 106-9. 'The strange, quirky Peter Fuller', who commissioned this article not long before he was killed in car crash, was described by Kitaj as the only art critic to emerge in the last thirty years of the twentieth century to match those of the previous generation; Kitaj, n.d., p. 61. There is much droll comment elsewhere on the likes of Dormant Dick, Anal Andy Dixon, Dame Brian R. Sewell and 'Mr Waldomar' (aka Waldemar Januscek) whom Kitaj, with typically facetious erudition, notes was the name of a London critic of fellow American Whistler at the end of the nineteenth century.
} 
read TARR almost 20 years ago!" 71 Just three years earlier he had in fact used the cover of Lewis's Caliph's Design as one of his 1969 'In Our Time' series of screenprinted book jackets. In January 1974 he responded positively to the idea of promoting Lewis's critique of avant-gardism: 'Your list of impending articles of attacks sounds very good - there is $\underline{\text { so }}$ much that needs to be said, needs to be done... The schools and journals and marketplaces are fetid and the various versions of Modernism continue to burden everything and everyone there... ${ }^{, 72}$

In his Second Diasporist Manifesto, published a few weeks before he ended his life, knowing better than George Steiner and John Carey that it was in fact a critique of anti-Semitism, Kitaj reproduced the cover of Lewis's The Jews are they Human $?^{73}$ Elsewhere in this final testament he wrote of his wish 'to invent a Jewish style, like the Egyptian figure style. ${ }^{74} \mathrm{He}$ knew well enough that the superb enduring visual culture of the ancient Egyptians had ultimately been destroyed by Judaism, via its monotheistic and aniconic legatees, Christianity and Islam. Warburgianly paradoxical to the last, however, as he had become more self-consciously Jewish, Kitaj also became less Judaicly 'text-centred' and more defiantly visual, eventually, in the footsteps of William Blake, breaking Moses' second commandment to the extent of depicting God Himself. ${ }^{75}$

\footnotetext{
${ }^{71}$ Letter to the present author, from his new address at 62 Elm Park Road, SW3, postmarked 19 October 1972 (Kitaj, 1972).

${ }^{72}$ Letter to the present author, postmarked 8 January 1974 (Kitaj, 1974). The 'In our Time' series was suggested by Walter Benjamin's essay entitled: 'Unpacking my Library: A Talk about Book Collecting' (first published in English in 1968) which praises the physicality of books; see Kinsman, 1994, chapter 5, though neither she nor Jennifer Ramkalawon discuss The Caliph's Design in particular. The title of the series presumably references Hemingway's collection of short stories, first published in 1924 by the Three Mountains Press in Paris with Modernist collage dust-jacket. This in turn was suggested by Ezra Pound and references the Book of Common Prayer's 'Give us peace in our time, O Lord'.

${ }^{73}$ Steiner's review of Paul Edwards' monograph (Observer, 7 August 2000) is subtitled 'Wyndham Lewis wrote outrageous anti-Jewish rhetoric' but although it reveals that he hadn't read The Jews are they Human? this is less disgraceful than John Carey's undocumented assertion of Lewis's antiSemitism (largely based on Jeffrey Meyer's flawed biography). See the chapter 'Wyndham Lewis and Hitler,' in Carey, 1992, pp.182-208. For a brilliant critique of Steiner's 'summary justice' on the question of T.S. Eliot's anti-Semitism, see Ricks, 1994, pp. 28-33. Kitaj found his copy of The Jews are they Human? in a Dulwich bookshop, as he tells us in his Confessions, Kitaj, n.d. p. 53.

${ }^{74} \mathrm{Kitaj}, 2007$, no. 70 . It is notable that he still aspired in this manifesto to achieve various aesthetic goals and describes himself as 75 years old, as if anticipating survival at least into his $76^{\text {th }}$ year. His reference to Egyptian art echoes an earlier one in his commentary on The Jewish School of 1980 (Kitaj, 1994, p. 138).

${ }^{75}$ He gave me permission to use this image on the cover of the New York Review Books Classics edition of G.B. Edwards' The Book of Ebenezer le Page, which was published in July 2007, a few months before he ended his life. In his Confessions (cit. Kitaj, n.d.) he expresses pride in the use authors and publishers have made of his pictures. Especially appropriate was NYRB Classics' use of
} 
Underpinned by the Warburgian notion of symbolic images he always retained the balance between form and content. When David Hockney wrote a brief introduction to the Christie's 2008 sale catalogue of Kitaj's collection, he said of his friend of fifty years that: 'he believed content was more important than form, although he also knew they were one. ${ }^{76}$ On the rare occasions Kitaj referred to this theoretical distinction he in fact asserted their essential equality but, following Warburg and Wind (rather than Wölfflin and Riegl) in this, in contrast to the majority of his twentieth-century contemporaries, certainly never prioritised 'formal values' over meaning. In his 1922 doctorate Wind had rejected contemporary art's privileging of formal values in art and Roger Fry and Clive Bell's art historical advocacy of the purely aesthetic response over historical analysis as merely Romantic. He later summarized his approach as one in which the intellect assisted rather than inhibited the imagination in producing great art:

I have tried to develop a method of interpreting pictures which shows how ideas are translated into images, and images sustained by ideas. ${ }^{77}$

It was extraordinarily astute of Kitaj to realize so early on in his life - when most of his contemporaries were enthusing about an aesthetic that was still restricted to a version of art-for-art's sake - that the then still obscure legacy of Aby Warburg might provide a superior guide to a creative as well as art-historical way forward. Thus, whilst never forgetting that form and content were inseparable, he focussed upon symbolic forms expressive of Pathos, or the Pathosformeln as Warburg had focussed upon them as an aid to understanding the art of antiquity and the transmissive nature of its Renaissance revival. ${ }^{78}$ Encouraged by the charismatic Edgar Wind, Kitaj expressed both ideas and emotions in the form of powerful images from his earliest days as a student in Oxford. Largely as a result, soon after his arrival in London at the

\footnotetext{
The Autumn of Central Paris (after Walter Benjamin) (1972-3) as the cover of Gershom Scholem's Walter Benjamin: The Story of a Friendship (2003).

${ }^{76}$ Christie's, 2008, p. 20.

${ }^{77}$ Application for a Guggenheim grant, 1950, Wind Archive, Department of Western Manuscripts, Bodleian Library, Oxford.

${ }^{78}$ Thus building upon, but in more psychologically profound ways, the already inclusive methods of his hero Jacob Burckhardt; see Warburg, 1999, pp. 9, 34-6.
} 
Royal College of Art he became one of the most influential artists of his generation. ${ }^{79}$ Surveying his fascinating career as a whole it becomes clear that Kitaj has few rivals in having maintained at such a superlative level the great tradition of figurative drawing and painting, the universal language that our cave-dwelling ancestors created and the Egyptians perfected so many thousands of years ago.

Edward Chaney is Professor of Fine and Decorative Arts and Chair of the History of Collecting Research Centre at Southampton Solent University. His most recent book, co-authored with Timothy Wilks, is The Jacobean Grand Tour (London: I.B. Tauris, 2014).

\footnotetext{
${ }^{79}$ David Hockney has stated that Kitaj, whilst still a student at the Royal College of Art, was 'a great influence on me, far more than any other factor; not just stylistically - he was a great influence stylistically on a lot of people, and certainly on me - but in his seriousness too.' So too has Allen Jones, who recalled recently that 'the most important lesson in that era was to see Kitaj painting...' See Luke, 2013 , p. 52.
} 


\section{Bibliography}

Agamben, 2011: Giorgio Agamben, 'Nymphs,' in Releasing the Image: From Literature to New Media, eds. Jacques Khalip and Robert Mitchell, Stanford: Stanford University Press, 2011, pp. 60-82.

Barnes, 1982: Janet Barnes, Percy Horton: Artist and Absolutist, 1897-1970, Sheffield: Graves Art Gallery, 1982.

Bartley, 2013: Tracy Bartley email to the author, 10 January 2013.

Bergstein, 2010: Mary Bergstein, Mirrors of Memory Freud, Photography, and the History of Art, Ithaca: Cornell University Press, 2010.

Bing, 1960: Gertrud Bing, 'Aby M. Warburg,' in Rivista storica italiana, 72, no. 1, 1960, pp. 100-113.

Brüne, 2007: Martin Brüne, 'On Human Self-domestication, Psychiatry, and Eugenics,' Philosophy, Ethics, and Humanities in Medicine, 2, no. 1 (January 2007), pp. 2-21. Accessible from http://www.peh-med.com/content/2/1/21.

Calman, 1960: Gerda Calman, 'The Picture of Nobody: An Iconographical Study,' in Journal of the Warburg and Courtauld Institutes, 23, pp. 60-104.

Carey, 1992: John Carey, The Intellectual and the Masses: Pride and Prejudice among the Literary Intelligentsia 1880-1939, London: Faber and Faber, 1992.

Cestelli Guidi and Mann, 1998. Benedetta Cestelli Guidi and Nicholas Mann, eds. Photographs at the Frontier: Aby Warburg in America 1895-1896, eds. Benedetta Cestelli Guidi and Nicholas Mann, London: Merrell Holbertson, 1998.

Chaney, 1990: Edward Chaney, 'Wyndham Lewis: The Modernist as Pioneering Anti-Modernist', Modern Painters, 3, no. 3, pp. 106-9.

Chaney, 2002: Edward Chaney, 'Kitaj versus Creed,' The London Magazine, April/May 2002, pp. 106-11.

Chaney, 2006: Edward Chaney, 'Egypt in England and America: The Cultural Memorials of Religion, Royalty and Revolution', in Sites of Exhange: European Crossroads and Faultlines, eds. M. Ascari and A. Corrado, Amsterdam: Rodopi, 2006, pp. 39-75.

Chaney, 2012: Edward Chaney, 'Warburgian Artist: R.B. Kitaj, Edgar Wind, Ernst Gombrich and the Warburg Institute,' in C. Kugelmann, E. Gillen and H. Gaßner, Obsessions: R.B. Kitaj 1932-2007, Berlin: Kerber Verlag, 2012, pp. 97-103.

Chernow, 1993: Ron Chernow, The Warburgs: The Twentieth-Century Odyssey of a Remarkable Jewish Family, New York: Random House, 1993. 
Christie's, 2008: Christie's Auction House, The Collection of R.B. Kitaj, Sale 7668, London: Christie's, 7 February 2008.

Churchill, Guy, Martin, and van Raay, 2004: Andrew Churchill, Frances Guy, Simon Martin and, Stefan van Raay, Modern British Art at Pallant House Gallery, London: Scala, 2004.

Clark, 1982: Kenneth Clark, Moments of Vision (1954), London: Harper Collins, 1982.

Fabbri, 2011: Paolo Fabbri, 'Beyond Gombrich: the recrudescence of visual semiotics', Journal of Art Historiography, no. 5 (December 2011), http://www.paolofabbri.it/saggi/beyond_gombrich.html; accessed 20 January 2013.

Farr, 2004: Dennis Farr, 'Wilde, Johannes (1891-1970)', Oxford Dictionary of National Biography, Oxford: Oxford University Press, 2004; online edn, Jan 2011 http://www.oxforddnb.com/view/article/36895, accessed 13 December 2013.

Frankfort, 2004: Enriqueta Frankfort, 'Bing, Gertrud (1892-1964)', Oxford Dictionary of National Biography, Oxford: Oxford University Press, 2004, http://www.oxforddnb.com/view/article/31887, accessed 13 December 2013.

Gombrich, 1984a: 'Two Minds,' London Review of Books, 6, no. 6, 5 April 1984, http://www.lrb.co.uk/v06/n06/letters; accessed 28 November 2013.

Gombrich, 1984b: Tributes: Interpreters of our Cultural Tradition, London: Phaidon, 1984.

Gombrich, 1986: E.H. Gombrich, Aby Warburg: An Intellectual Biography, second ed., Oxford: Phaidon Press, 1986.

Gombrich, 1993: E.H. Gombrich, A Lifelong Interest: Conversations on Art and Science with Didier Eribon, London: Thames and Hudson, 1993.

Gombrich, 1995: E.H. Gombrich, Shadows: The Depiction of Shadows Cast in Western Art. London: National Gallery Publications, 1995.

Gombrich, 1997: E.H. Gombrich, The Visual Arts in Vienna, circa 1900; \&, Reflections on the Jewish Catastrophe, preface by Emil Brix, London: Austrian Cultural Institute, 1997.

Gombrich, 1999: E.H. Gombrich, 'Aby Warburg: His Aims and Methods: An Anniversary Lecture', Journal of the Warburg and Courtauld Institutes, 62, pp. 268282.

Gore, 2004: Frederick Gore, 'Fitton, James (1899-1982)', Oxford Dictionary of National Biography, Oxford: Oxford University Press, 2004; online edn, May 2006, http://www.oxforddnb.com/view/article/31109, accessed 13 December 2013. 
Green, 2013: Brian Green, 'Dulwich Artist In Residence - R B Kitaj (1932-2007),' The Dulwich Society, http://www.dulwichsociety.com/2013-spring/810-ronaldbrooks-kitaj; accessed 28 November 2013.

Hope, 1984: Charles Hope, 'Naming the Graces,' in London Review of Books, 6, no. 5 (15 March 1984), pp. 13-14.

Iversen, 1991: Margaret Iversen, 'Aby Warburg and the New Art History', Aby Warburg. Akten des Internationalen Symposions Hamburg 1990, eds H. Bredekamp, Michael Diers and C. Schoell-Glass, Hamburg: Wiley-VCH Verlag, 1991, pp. 281-87.

Kinsman, 1994: Jane Kinsman, The Prints of R.B. Kitaj, Aldershot: Scolar Press, 1994.

Kitaj, 1963: R.B. Kitaj, Pictures with Commentary: Pictures without Commentary, exh. cat., London: Marlborough Fine Art, February 1963.

Kitaj, 1972: R.B. Kitaj letter to the author, postmarked 19 October, 1972.

Kitaj, 1974: R.B. Kitaj letter to the author, postmarked 8 January 1974.

Kitaj, 1994: R.B. Kitaj: A Retrospective, ed. Richard Morphet, exh. cat., London: Tate Gallery, 1994.

Kitaj, 1997: 'R.B. Kitaj and David Hockney discuss the case for a return to Figuration', New Review, 3, no. 34-5, pp. 75-7.

Kitaj, 2003: R.B. Kitaj Los Angeles Pictures, exh. cat., Venice, CA: L.A. Louver Gallery: 2003.

Kitaj, 2007: R.B. Kitaj, Second Diasporist Manifesto, New Haven: Yale University Press, 2007.

Kitaj, n.d.: R.B. Kitaj, Confessions (unpublished autobiography; courtesy of Lem Dobbs and the Kitaj Estate).

Kugelmann, Gillen and Gaßner, 2012: C. Kugelmann, E. Gillen and H. Gaßner, Obsessions: R.B. Kitaj (1932-2007), Berlin: Kerber Verlag, 2012.

Lambirth, 2004: Andrew Lambirth, Kitaj, London: PWP Contemporary Art, 2004.

LBI: New York, Leo Baeck Institute, Archives, Walter Friedlaender Collection, AR 3393, http://www.archive.org/stream/walterfriedlaender_01_reel01\#page/n801/mode/1up; accessed 11 December 2013.

Livingstone, 2010: Marco Livingstone, Kitaj, fourth ed., London: Phaidon, 2010. 
Lloyd-Jones, 1983: Hugh Lloyd-Jones, 'A Biographical Memoir', in Edgar Wind, The Eloquence of Symbols, Studies in Humanist Art, ed. Jaynie Anderson, Oxford: Oxford University Press, 1983, pp. xiii-xxxvi.

Luke, 2012: Ben Luke, 'The School of Pop', Apollo, 177, no. 605 (January 2013), p. 50-55.

Marazia and Stimilli, 2007: C. Marazia and D. Stimilli eds., Ludwig Binswanger, Aby Warburg: Die unendliche Heilung: Aby Warburgs Krankengeschichte, Berlin: Diaphanes, 2007.

McCully, Raeburn, and Watson, 2011: Marilyn McCully, Michael Raeburn and Helen Watson, Kitaj: Portraits and Reflections, Kendal: Abbot Hall Art Gallery, 2011.

McGrath, 2008: Elizabeth McGrath, 'Obituary: Michael Baxandall,' The Guardian, 26 August 2008, p. 30.

http://www.theguardian.com/artanddesign/2008/aug/26/historyandhistoryofart; accessed 28 November 2013.

McGrath, 2014: Elizabeth McGrath, 'Gombrich and "Warburgian” Iconography', in Meditations on a Heritage, ed. Paul Taylor, London, 2014, forthcoming.

McEwan 2013: Dorothea McEwan, Fritz Saxl: Eine Biografie, Vienna and Cologne: Boehlau Verlag, 2013.

Michaud, 2004: Philippe-Alain Michaud, Aby Warburg and the Image in Motion, New York: Zone Books, 2004.

Michels, 1999: Karen Michels, 'Art History, German Jewish Identity, and the Emigration of Iconology', Jewish Identity in Modern Art History, ed. Catherine M. Soussloff, Berkeley: University of California Press, 1999, pp. 167-79.

Neumeyer, 1938: Alfred Neumeyer, 'Monuments to 'Genius' in German Classicism', Journal of the Warburg and Courtauld Institutes, 2, no. 2, pp. 159-63.

NPG: National Portrait Gallery, London, Archive, NPG46/59/79, Registered Packet 5892.

Onians, 2011: John Onians, 'Michael David Kighly Baxandall 1933-2008,' Proceedings of the British Academy, 166, Biographical Memoirs of Fellows, IX, pp. 26-46.

Pliny: Pliny, the Elder, Natural History, trans. H. Rackham, W.H.S. Jones and D.E. Eichholz, London: Heinemann, 1938-1963, 10 vols.

Pollock, 2013: Griselda Pollock, 'Aby Warburg and "Thinking Jewish" in Modernity', Thinking Jewish Modernity: Thinkers, Writers, Artists, Shapers of Jewish Modernity, eds Jacques Picard, Jacques Revel, Michael Steinberg and Idith Stertal Basel: University of Basel, 2013, forthcoming. 
Prinzhorn, 2011: Hans Prinzhorn, American Journal of Psychiatry, http://ajp.psychiatryonline.org/data/Journals/AJP/4236/appi.ajp.2011.11040571.pdf; accessed 28 November 2013.

Ramkalawon, 2013: Jennifer Ramkalawon, Kitaj Prints: A Catalogue Raisonne, exh. cat. London: The British Museum, 2013.

Richardson, 2008: John Richardson, A Life of Picasso: The Triumphant Years: 19171932, Volume 3, London: Knopf, 2008.

Ricks, 1994: Christopher Ricks, T.S. Eliot and Prejudice, London: Faber and Faber, 1994.

Robertson, Russell and Snowdon, 1965: Bryan Robertson, John Russell and Lord Snowdon, Private View: The Lively World of British Art, London: Thomas Nelson and Sons, 1965.

Roeck, 2009: Bernd Roeck, Florence 1900: The Quest for Arcadia, New Haven and London: Yale University Press, 2009.

Rosen, 2009: Aaron Rosen, Imagining Jewish Art: Encounters with the Masters in Chagall, Guston, and Kitaj, London: Legenda, 2009.

Roth, 1995: Phillip Roth, Sabbath's Theater, Boston: Houghton Mifflin, 1995.

Roth, 2000: Phillip Roth, The Human Stain, Boston: Houghton Mifflin Harcourt, 2000 .

Rudolf and Wiggins, 2002: Anthony Rudolf and Colin Wiggins, Kitaj in the Aura of Cézanne and other Masters, London: National Gallery, 2002.

Sanchez-Juaregui and Wilcox, 2012: The English Prize: The Capture of the "Westmoreland," an Episode of the Grand Tour, eds. M.D. Sanchez-Jauregui and Scott Wilcox, New Haven: Yale University Press, 2012.

Saumarez Smith, 2006: Charles Saumarez Smith, 'Old Master,' The Guardian, 2 December 2006, http://www.theguardian.com/books/2006/dec/02/art; accessed 28 November 2013.

Schama, 2013: Simon Schama, The Story of the Jews: Finding the Words (1000 B.C.E-1492), London: Bodley Head, 2013.

Schoell-Glass, 1999: Charlotte Schoell-Glass, 'Aby Warburg: Forced Identity and Cultural Science' in Jewish Identity in Modern Art History, ed. Catherine M.

Soussloff, Berkeley: University of California Press, 1999, pp. 281-30.

Schoell-Glass, 2008: Charlotte Schoell-Glass, Aby Warburg and Anti-Semitism: Political Perspectives on Images and Culture, Detroit: Wayne State University Press, 2008. 
Shachar, 1974: Isaiah Shachar, The Judensau: A Medieval Anti-Jewish Motif and Its History, London: Warburg Institute, 1974.

Shachar, 1993: Isaiah Shachar, The Visual Dimension: Aspects of Jewish Art, published in memory of Isaiah Shachar, (1935-1977) ed. Clare Moore, Boulder: Westview Press, 2003.

Stubblebine, 1996: James H. Stubblebine ed., Giotto: The Arena Chapel Frescoes, Norton Critical Studies in Art History, New York: W. W. Norton and Company, 1996.

Thomas, 2009: Ben Thomas, 'An Art Historian's Dilemma', paper presented to Writing Art History: On the Agenda? Courtauld Institute Research Forum, Courtauld Institute of Art, London, 14 February.

UCLA: University of California, Los Angeles, R.B. Kitaj papers (Collection Number 1741), Department of Special Collections, Charles E. Young Research Library, University of California, Los Angeles.

Warburg, 1999: Aby Warburg, The Renewal of Pagan Antiquity, introduction by. K.W. Forster, trans. David Britt, Los Angeles: Getty Research Institute, 1999.

Wind, 1937: Edgar Wind, 'The Maenad Under The Cross: Comment on an Observation by Reynolds,' Journal of the Warburg Institute, 1, pp. 70-1.

Wind, 1964: Edgar Wind, Art and Anarchy, London: Knopf, 1964.

Wind, 1983: Edgar Wind, The Eloquence of Symbols: Studies in Humanist Art, ed. Jaynie Anderson, Oxford: Oxford University Press, 1983.

Wind, 1986: Edgar Wind, Hume and the Heroic Portrait: Studies in EighteenthCentury Imagery, ed. J. Anderson, Oxford: Oxford University Press, 1986, pp. 74-80.

Wittkower, 1942: Rudolph Wittkower, 'Marvels of the East: A Study in the History of Monsters,' in Journal of the Warburg and Courtauld Institutes, 5, pp. 159-197. 


\section{List Of Illustrations}

Fig.1. Photograph of R.B. Kitaj at Elm Park Gardens soon after his heart attack, with unfinished Melancholy after Dürer (1989). (Copyright Jonathan Player.)

Fig. 2. R.B. Kitaj, Sir Ernst Hans Josef Gombrich, 1986. Pastel and charcoal, $67.6 \mathrm{x}$ $57.8 \mathrm{~cm}$ London, National Portrait Gallery, inv. no. NPG 5892 (National Portrait Gallery).

Fig. 3. Unknown photographer, Edgar Wind. (Copyright Wind Benefaction Committee for the Sackler Library, University of Oxford.)

Fig. 4. Percy Horton, Self Portrait, 1946. (Edward Chaney collection.)

Fig. 5. Aby Warburg with Hopi Indian, 1895. (Photograph: Warburg Institute.)

Fig. 6. R.B. Kitaj, Warburg as a Maenad, 1961-2. (Courtesy Kitaj Estate.)

Fig. 7. R.B. Kitaj, The Murder of Rosa Luxemburg, 1960. (Courtesy Kitaj Estate.)

Fig. 8. R.B. Kitaj, Specimen Musings of a Democrat, 1961. (Pallant House Gallery.)

Fig. 9. R.B. Kitaj, Los Angeles No. 17 (Zip), 2002. (Courtesy Kitaj Estate.)

Fig. 10. Giotto, Arena Chapel Frescoes (detail), ca. 1305. (Scrovegni Chapel, Padua.)

Fig. 11. R.B. Kitaj, Los Angeles No. 22 (Painting-Drawing), 2001. (Marlborough Fine Art.)

Fig. 12. David Allan, The Origin of Painting (The Maid of Corinth), 1775. Oil on panel, 51.5 x $44.1 \mathrm{~cm}$, Edinburgh, Scottish National Gallery, NG612. (Scottish National Gallery.) 